\title{
QUARTERLY PROGRESS REPORT \\ RESEARCH AND DEVELOPMENT ACTIVITIES \\ WASTE FIXATION PROGRAM \\ JULY THROUGH SEPTEMBER 1973
}

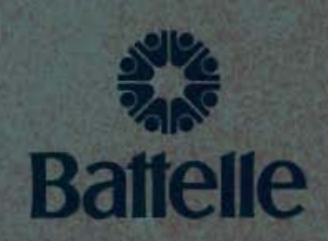

Pacific Northwest Laboratories

Richland, Washington 99352

OCTOBER 1973

Prepared for the U.S. Atomic Energy

Commission under Contract AT(45-1):1830 


\title{
NOTICE
}

The report was prepared as an account of work sponsored by the United States Government. Neither the United States nor the United States Atomic Energy Commission, nor any of their employees, nor any of their contractors, subcontractors, or their employees, makes any warranty, express or implied, or assumes any legal liability or resporisibility for the accuracy, completeness or usefulness of any information, apparatus, product or process disclosed, or represents that its use would not infringe privately owned rights.

\author{
PACIFIC NORTHWEST LABORATORY \\ operated by \\ BATTELLE \\ for the \\ U.S. ATOMIC ENERGY COMMISSION \\ Under Contract AT(45-1)-1830
}

\author{
Printed in the United States of America \\ Available from \\ National Technical Information Service \\ U.S. Department of Commerce \\ 5285 Port Royal Road \\ Springfield, Virginia 22151 \\ Price: Printed Copy 55,45; Microfiche 50.95
}

AECAL NICHLAKD, WAEH. 


\title{
33679000623035
}

BNWL-1788

UC -70

Waste Disposal

and Processing

\author{
QUARTERLY PROGRESS REPORT \\ RESEARCH AND DEVELOPMENT ACTIVITIES \\ WASTE FIXATION PROGRAM \\ July through September 1973
}

Compiled by

A. M. Platt

Nuclear Waste Technology Department

October 1973

BATTELLE

PACIFIC NORTHWEST LABORATORIES

RICHLAND, WASHINGTON 99352 
TABLE OF CONTENTS

LIST OF FIGURES
LIST OF TABLES
INTRODUCTION
SUMMARY

COMMERCIAL WASTE SOLIDIFICATION • . . • . . . .

LABORATORY STUDIES • • . . . . . . • . • . . 3

High-Temperature Melt Formations . . . . . . . 3

Microcrystalline Ceramic Product Forms . . . . . 5

Ceramic Melter: Materials Compatibility . . . . . 7

Waste Vaporization Studies . • . . . . . .

ENGINEERING STUDIES . . . . . . . . . . . . . 13

Developmental Spray Calciner and Inconel Melter . . 13

Wiped Film Evaporator . . . . . . . • . . 24

Fluidized Bed Calcination Studies . • • • . . 26

Direct-Coupling Induction Melter • . • . . . 27

AEC WASTE SOLIDIFICATION • • . • • • • • • . . 28

ELECTRIC GLASS TANKS • • • • • • • • • • • • 28

MOLYBDENUM ELECTRODE GLASS-MELTING FURNACE • • • • • 28

RADIOACTIVE DEMONSTRATIONS • • . • • • • • . . . 30

RADIOACTIVITY FOR WFP DEMONSTRATION RUNS . . . . . 30

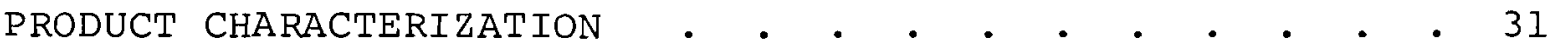

INTERIM STORAGE OF WSEP CANISTERS . • . • • . . . . 31

Measurements on Core-Drilled Samples . . . . . . 31

Thermowell Leaks in WSEP Canisters . . . . . . . 32 
Analysis of Thermowell Failures • • • • • • • 32

HELIUM BUILDUP IN WASTE GLASS • • • • • • • • • 35

Helium Production Rate • • . . . . . . . 36

Solubility and Diffusivity of Helium in Glass . • . 36

Mechanical Strength of Glass . . . . . . . • . 39

Internal Stress in Waste Glass . . . . . . . . 40

Conclusions • • • • • • • • • • • • • 41 


\section{LIST OF FIGURES}

1 Microstructure of Refractories Exposed to Molten Glass in $\mathrm{Air}$ at $1450^{\circ} \mathrm{C}$ (Interface Cross Section)

2 Microstructure of Fused Cast $60 \% \mathrm{Al}_{2} \mathrm{O}_{3}, 27 \% \mathrm{Cr}_{2} \mathrm{O}_{3}$ Exposed to Molten Glass in Air for 108 Hours (Interface Cross Section)

3 Process Flow Diagram for Developmental Spray Solidifier 15

4 Detail of Canister Thermowell Weld

5 Correlation of Diffusion Coefficient and Solubility for Helium in Glass at $200^{\circ} \mathrm{C}$

6 Time Dependent Maximum Internal Stress in Waste Glass for Different Sample Geometries

\section{LIST OF TABLES}

1 Effect of Varying Glass-Making Agent:Waste Calcine Ratio in Melt 73-109

2 Comparison of Leach Rate of Melt with Commercial Bottle Glass

3 Operating Parameters and Results of Development Spray Solidification Runs DSS-1 through DSS-5

4 Leachability of WSEP In-Pot Melting Borosilicate Glass Product after 2.8 Years Storage at Approximately $60^{\circ} \mathrm{C}$ Wall Temperature 


\author{
QUARTERLY PROGRESS REPORT \\ RESEARCH AND DEVELOPMENT ACTIVITIES \\ WASTE FIXATION PROGRAM \\ July through september 1973
}

INTRODUCTION

This progress report is the fourth in a series that presents research and development activities in the field of radioactive waste fixation. Previous progress reports were BNWL-1699, 1741, and 1761 .

\title{
SUMMARY
}

The aim of the melt development program is to produce melt-formed ceramic products which have the optimum combination of physical properties for the fixation of radioactive wastes. Depending upon thermal treatment many of the ceramics can be in either a glassy or a microcrystalline form. Laboratory and nonradioactive pilot plant tests are being conducted to evaluate both forms.

Both $\mathrm{PW}-4 \mathrm{~b}$ and $\mathrm{PW}-6$ waste compositions have been successfully solidified into borosilicate glass in the development spray solidifier. Calciner wall scaling was minimal and offgas filter differential pressure remained low during over 26 hours operation in five runs. Glass formation and discharge from the melter proceeded smoothly at melt temperatures ranging from 1050 to $1175^{\circ} \mathrm{C}$.

Discussions were held with glass industry representatives concerning the design and fabrication of electric glass tanks for the vitrification of high-level wastes. Melting tests in 
an industrial electric glass tank are planned to check the feasibility of this approach and to obtain design data; a laboratory-scale unit has also been constructed to gain firsthand experience.

A series of tests and a stress analysis have shown with good assurance that the leaks which have appeared in the thermowells of several of the WSEP canisters are located at the weld where the thermowells enter the canisters. The welds are located well above the product level in the canisters and the failures are due to stress rather than corrosion.

Calculations of helium buildup in waste glass canisters indicate that internal stresses due to helium gas production from the decay of actinide nuclides in the waste may produce sufficient strain to induce cracking of the glass. However, cracking may be avoided by fabricating waste glasses in the form of spheres less than about $8 \mathrm{~cm}$ in diameter. 


\section{COMMERCIAL WASTE SOLIDIFICATION}

\section{LABORATORY STUDIES}

High-Temperature Melt Formations - J. E. Mendel and I. M. Warner

The high-temperature melt formulations are being developed for a process in which high-level waste calcine and glass-making agents are added to a melter as separate streams. Considerable variation from the nominal flow rates of the two streams should be tolerable without greatly affecting process operation or product quality. Tests were made on the effect of variations in the glass-making additives:waste calcine ratio for a promising high-temperature melt formulation (Melt 73-109, Table 1, BNWL-1761).

The glass-making agents added to produce Melt 73-109 are:

$\begin{array}{lr}\mathrm{SiO}_{2} & 73.0 \text { wt\% } \\ \mathrm{ZnO} & 17.9 \text { wt\% } \\ \mathrm{ZrO}_{2} & 9.1 \text { wt\% }\end{array}$

The nominal flowsheet uses a glass-making agent:waste calcine ratio of $2.33: 1$. Test melts were prapared in which the ratio was varied from 19:1 to 1.22:1 (Table 1). The results indicate the operating range for which optimum product can be obtained is rather narrow for this flowsheet, ranging from a lower limit of glass-making agent:waste calcine ratio of about $1.5: 1$ to an upper limit of about $3: 1$. The lower limit is imposed by nonhomogeneity and increased leachability; the upper limit by nonhomogeneity and rapidly increasing viscosity.

Melt 73-109 was developed using PW-6 (high sodium) waste. The Melt 73-109 glass-making agents are not suitable for processing $\mathrm{PW}-4 \mathrm{~b}$ waste without modification, as shown by the bottom entry in Table 1 . Obviously, by adding sodium and iron, $\mathrm{PW}-4 \mathrm{~b}$ 
H: : : :m:

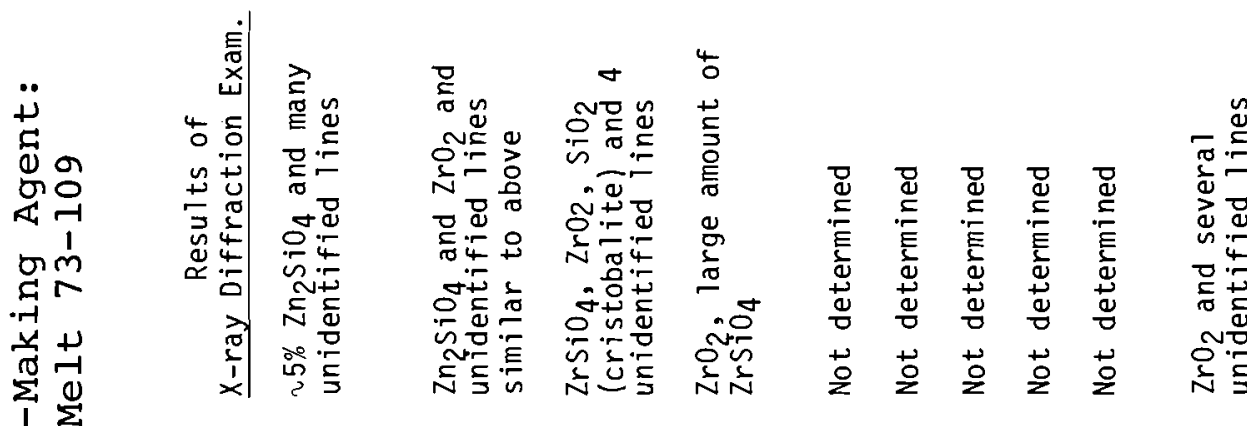

on

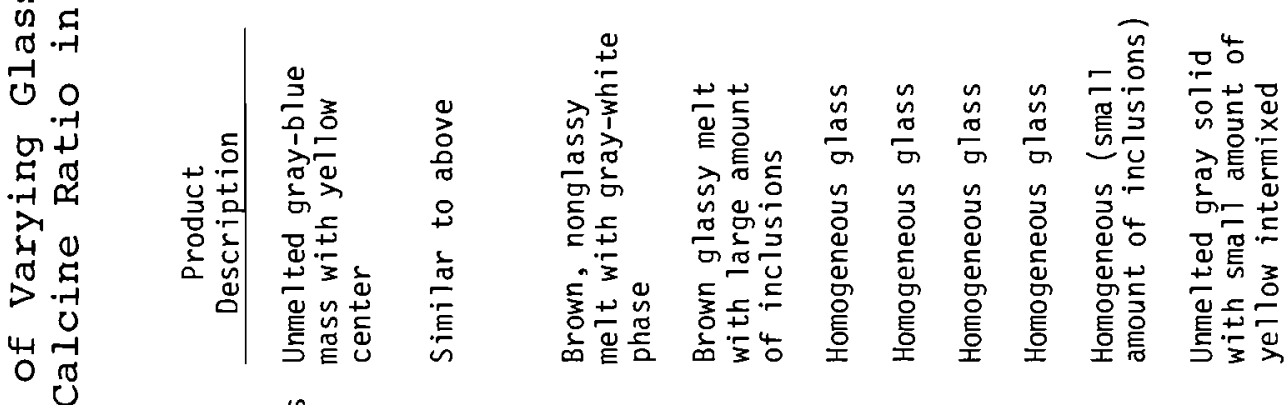

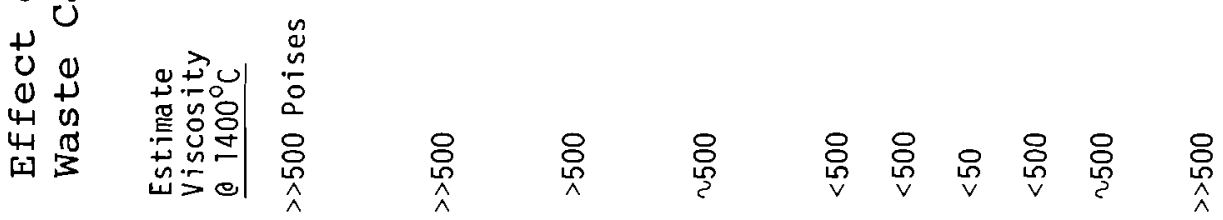

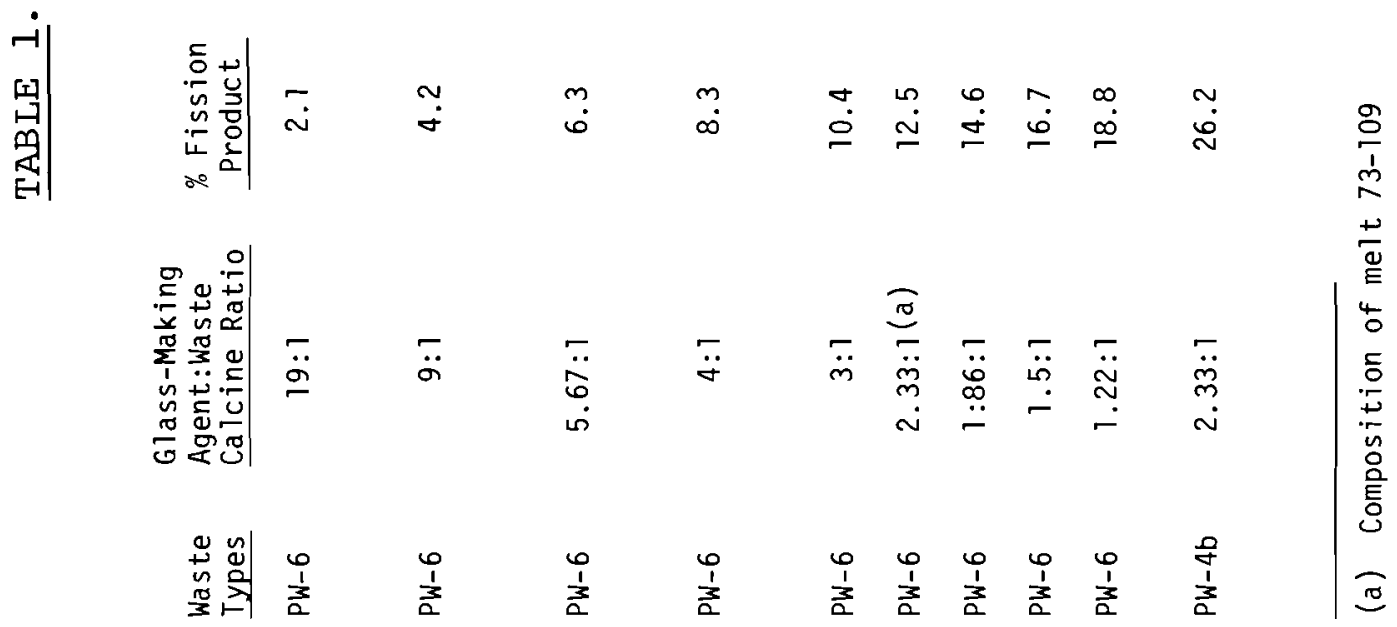


waste can in effect be changed to PW-6 waste and processed by the Melt 73-109 flowsheet. However, a factor of 2 dilution occurs. This illustrates a significant characteristic of the high-temperature, or high-silica (>50 wto) melt formulations: they are limited to a lower concentration of fission products than can be assimilated in the low-melting, low-silica melt formulations.

A principal advantage of high-temperature, high-silica waste melt formulations is increased leach resistance. The leach rate of Melt 73-109 is about a factor of 10 lower than that of a typical low temperature waste melt (Melt 72-68) over the temperature range 25 to $85^{\circ} \mathrm{C}$. In fact, in tests over this temperature range the chemical durability of Melt 73-109 even exceeded that of a commercial soda lime bottle glass (see Table 2).

Microcrystalline Ceramic Product Forms - J. E. Mendel, W. A. Ross, J. L. Bates and W. F. Bonner

In most of the flowsheets being developed for high-level waste fixation the final solidified product is a massive cylinder with a diameter of about 8 inches, encased in a steel can. The borosilicate glasses made with this geometry in the WSEP program were highly fractured inside their steel canisters due to thermal stresses, and industrial experience indicates it would be very difficult to prevent such fracturing. Conversely, core drilling of the microcrystalline products made in the WSEP program has shown that most of them have remained essentially monolithic, thus preserving the low surface-to-volume ratio which should be one of the advantages of a melt forming process. Drop tests made during the WSEP program demonstrated that under impact the glassy products fractured into many small particles while the microcrystalline products fractured into a 


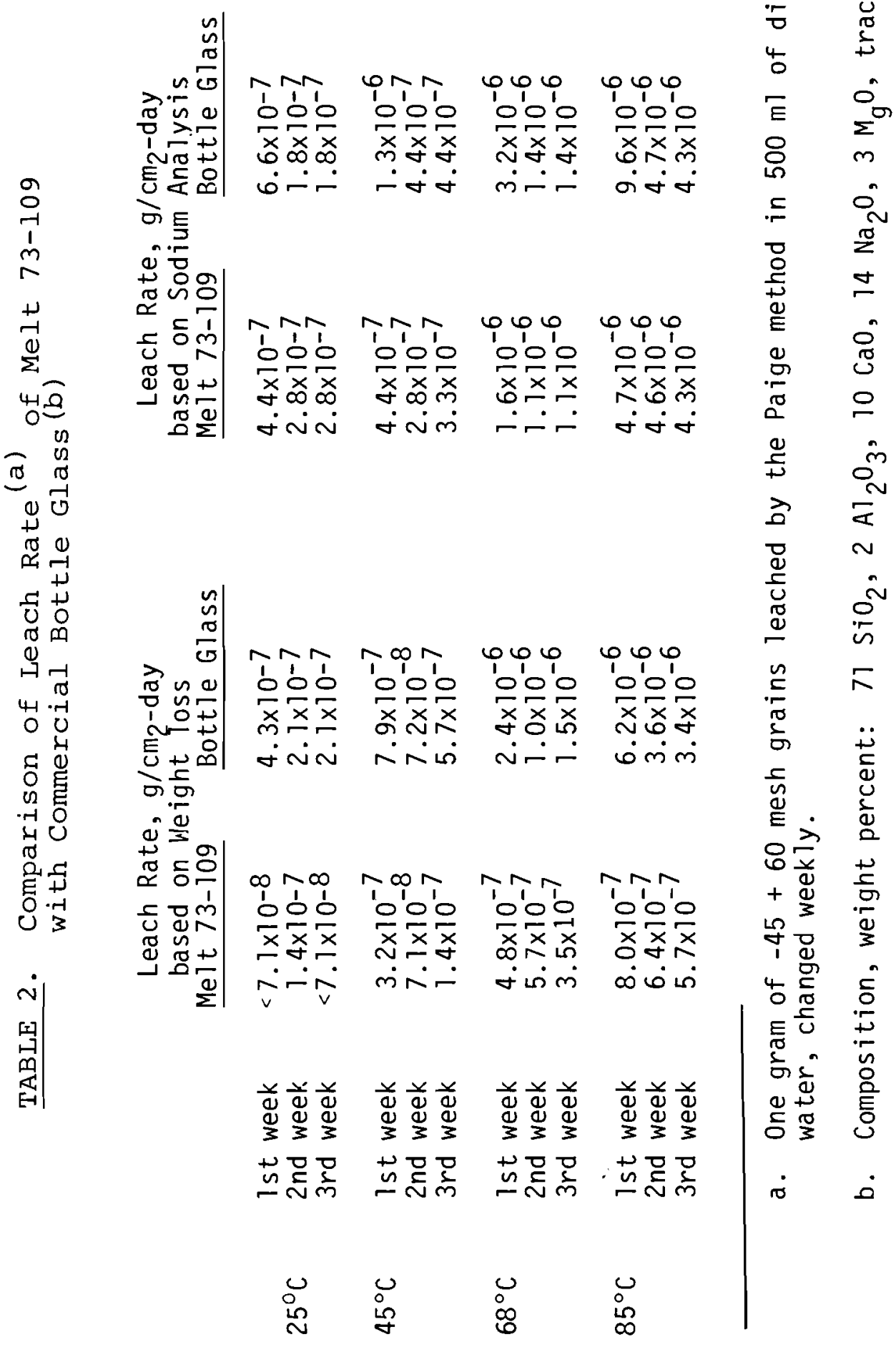


few larger particles. These results illustrate that microcrystalline materials can be more thermal shock resistant and tougher than true glasses. Microcrystalline products also have other advantages:

- Final physical form can be defined with more assurance; glasses are less stable thermodynamically and are potentially subject to further changes at storage temperatures.

- Softening point of microcrystalline products is higher.

For these reasons it is very possible that microcrystalline waste forms are more suitable than true glasses for high-level radioactive waste fixation. While the very small crystallites of a glass-ceramic or pyroceram may be optimum, they are usually obtained in industry only by careful control of composition and processing temperature. The degree of control required of these parameters may be impractical in a high-level radioactive waste processing plant, but WSEP experience indicates that the advantages of increased physical toughness, thermal shock resistance and higher melting point may not require stringent control of crystal size.

As described in the previous quarterly, devitrification tests are being conducted on certain melt compositions in the laboratory. As canisters of product begin to be produced in the nonradioactive pilot plant they also will be subjected to controlled thermal treatment to produce crystalline or glassy forms and the results will be correlated with laboratory tests. The effect of crystallization upon leach rate is being examined in the laboratory. It is also planned to begin testing the effects of special additives upon crystallization behavior. Ceramic Melter: Materials Compatibility - J. L. Bates and J. J. Rasmussen

Compatibility testing of ceramic refractories in a high temperature glass waste (Melt 73-109) have been underway to 
select potential materials for constructing a ceramic lined melter. Nine refractory compounds were exposed at $1450^{\circ} \mathrm{C}$ to the waste glass containing 51.1 wto $\mathrm{SiO}_{2}, 12.5$ wto $\mathrm{ZnO}$, 6.3 wt: $\mathrm{ZrO}_{2}$, and 30 wto high-level simulated calcine (PW-6). Each sample was cut as a parallelepiped approximately 0.4 inch square and $1-1 / 2$ to 2 inches long.

The waste glass was melted in air in a platinum crucible to $1450^{\circ} \mathrm{C}$ with the sample suspended in the hot zone of the furnace directly above the glass. On reaching the desired temperature, the sample was lowered into the glass on a platinum wire. One half of the sample was immersed while the other half remained out of the liquid. Each sample was initially exposed for 48 hours in the molten glass, quickly removed within approximately 20 seconds, and wrapped in a refractory wool to reduce thermal shock. The samples were then sectioned and examined ceramographically. Sibling samples of the compositions which exhibited the least amount of interaction with the molten glass were heated at $1450^{\circ} \mathrm{C}$ for 168 hours and examined.

Three samples of commercially supplied refractories exhibited significantly better resitance to the molten glass. These include cast zirconia $\left(295 \% \mathrm{ZrO}_{2}\right)$ fused cast chrome ore $\left(80 \% \mathrm{Cr}_{2} \mathrm{O}_{3}\right.$ ), and silicon carbide. An isostatically pressed chrome ore $\left(80 \% \mathrm{Cr}_{2} \mathrm{O}_{3}\right)$ exhibited moderate resistance to attack, but not as good as the fused cast chrome ore with a similar composition. Those refractories which showed poor resistance to chemical attack were fused cast $\mathrm{Al}_{2} \mathrm{O}_{3}(60 \%)-\mathrm{Cr}_{2} \mathrm{O}_{3}(27 \%)$, fused cast ZAS ( $41 \% \mathrm{ZrO}_{2}, 47 \% \mathrm{Al}_{2} \mathrm{O}_{3}$, and $\left.11 \% \mathrm{SiO}_{2}\right)$, and fused cast $\mathrm{Al}_{2} \mathrm{O}_{3}(95 \%)$.

The preliminary results suggest that the presence of a high $\mathrm{Al}_{2} \mathrm{O}_{3}$ phase in the refractory may increase the susceptibility to chemical attack. Figure 1 illustrates the representative microstructure of three samples after exposure to the 
molten glass. The SiC showed no evidence of reaction (Figure la). The fused chrome ore exhibited very slight indications of attack as evidenced by the very small areas of breakup at the as-cut surface and the apparent removal of some of the lighter-colored phases from the surface (Figure lb). The zirconia sample, which was originally porous, showed penetration of the glass into the pores with some very small but not positive evidence of surface degradation (Figure 1c). The fused case chrome-alumina showed massive areas of surface reaction as illustrated in Figure 2. The glass caused gross breakup of the surface and apparent dissolution of the lighter-colored phase (apparently high in $\mathrm{Al}_{2} \mathrm{O}_{3}$ ) and ultimate precipitation or growth of $\mathrm{Al}_{2} \mathrm{O}_{3}-$ rich crystals in the glass near the glass-refractory interface. All other samples containing large percentages of $\mathrm{Al}_{2} \mathrm{O}_{3}$ exhibited similar surface breakup. However, with one exception, the reaction was limited to the surface and did not penetrate into the refractory.

It is concluded that for the $\mathrm{SiO}_{2}$-Sno-Zro $_{2}$-calcine glass composition, high chrome, zirconium oxide, or silicon carbide samples will exhibit the best resistance to attack by the molten glass. Characterization of these samples is continuing, and new samples are being exposed to the molten glass for evaluation.

Waste Vaporization Studies - W. J. Gray

The purpose of this study is to investigate the vaporization behavior of fission-product-containing wastes during processing, shipment, and storage. Accident conditions involving high temperatures and breach of the container during shipment and storage are of particular interest.

Two types of exploratory experiments have been made with fluidized bed calcine from Run $\mathrm{PW}-4 \mathrm{~b}-5$. 

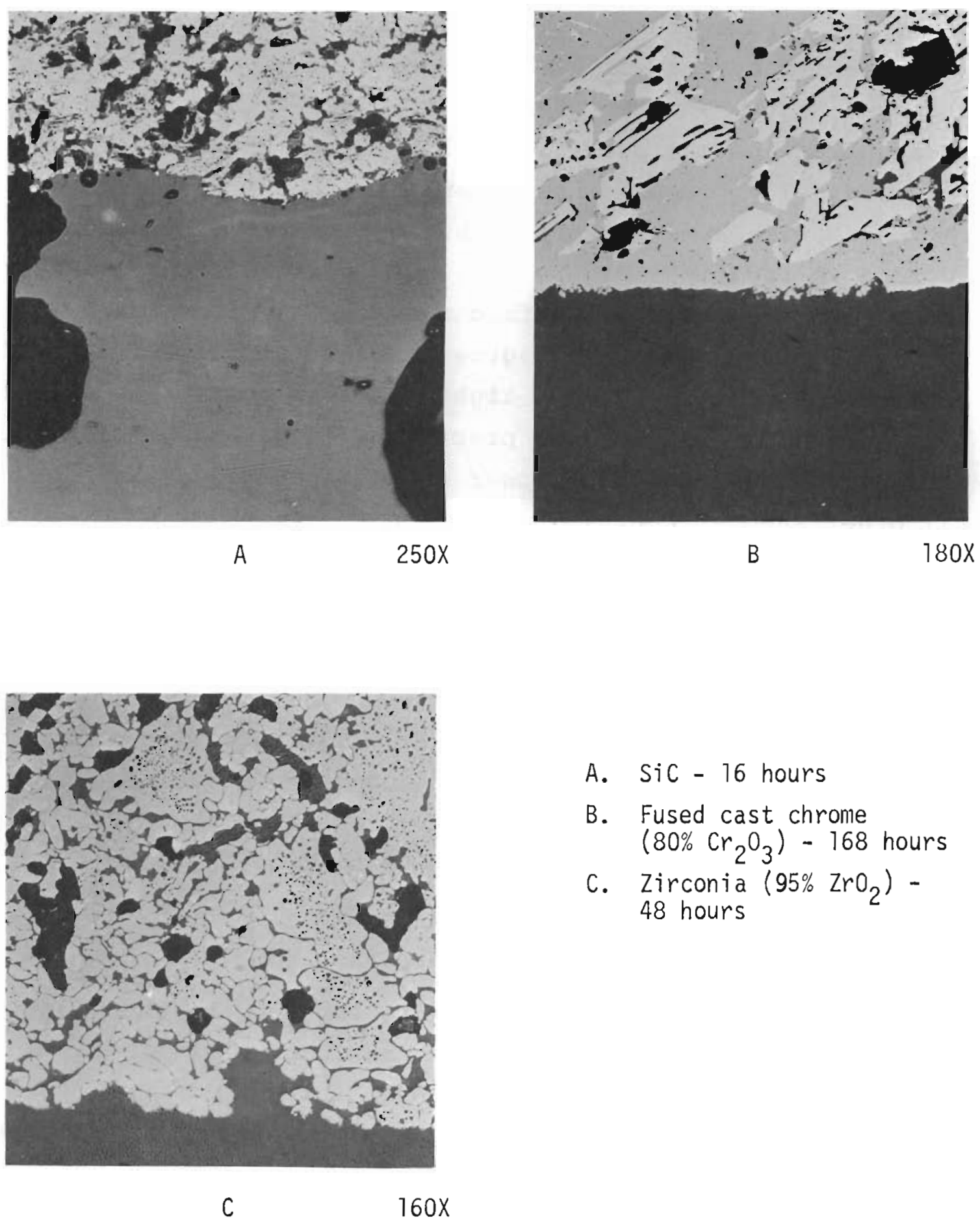
A. SiC - 16 hours
B. Fused cast chrome $\left(80 \% \mathrm{Cr}_{2} \mathrm{O}_{3}\right)-168$ hours
c. Zirconia $\left(95 \% \mathrm{ZrO}_{2}\right)$ - 48 hours

FIGURE 1. Microstructure of Refractories Exposed to Molten Glass in Air at $1450^{\circ} \mathrm{C}$ (Interface Cross Section) 


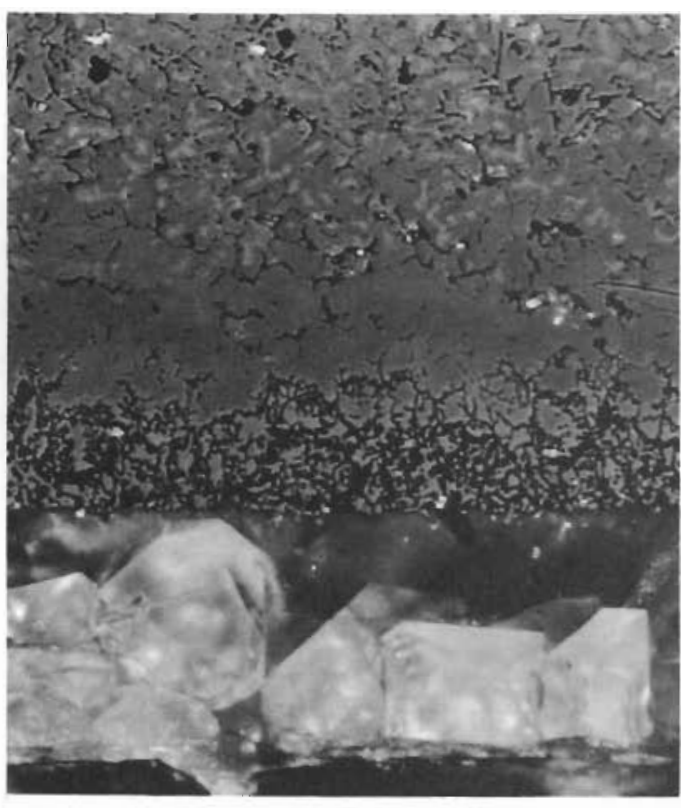

Polarized Light
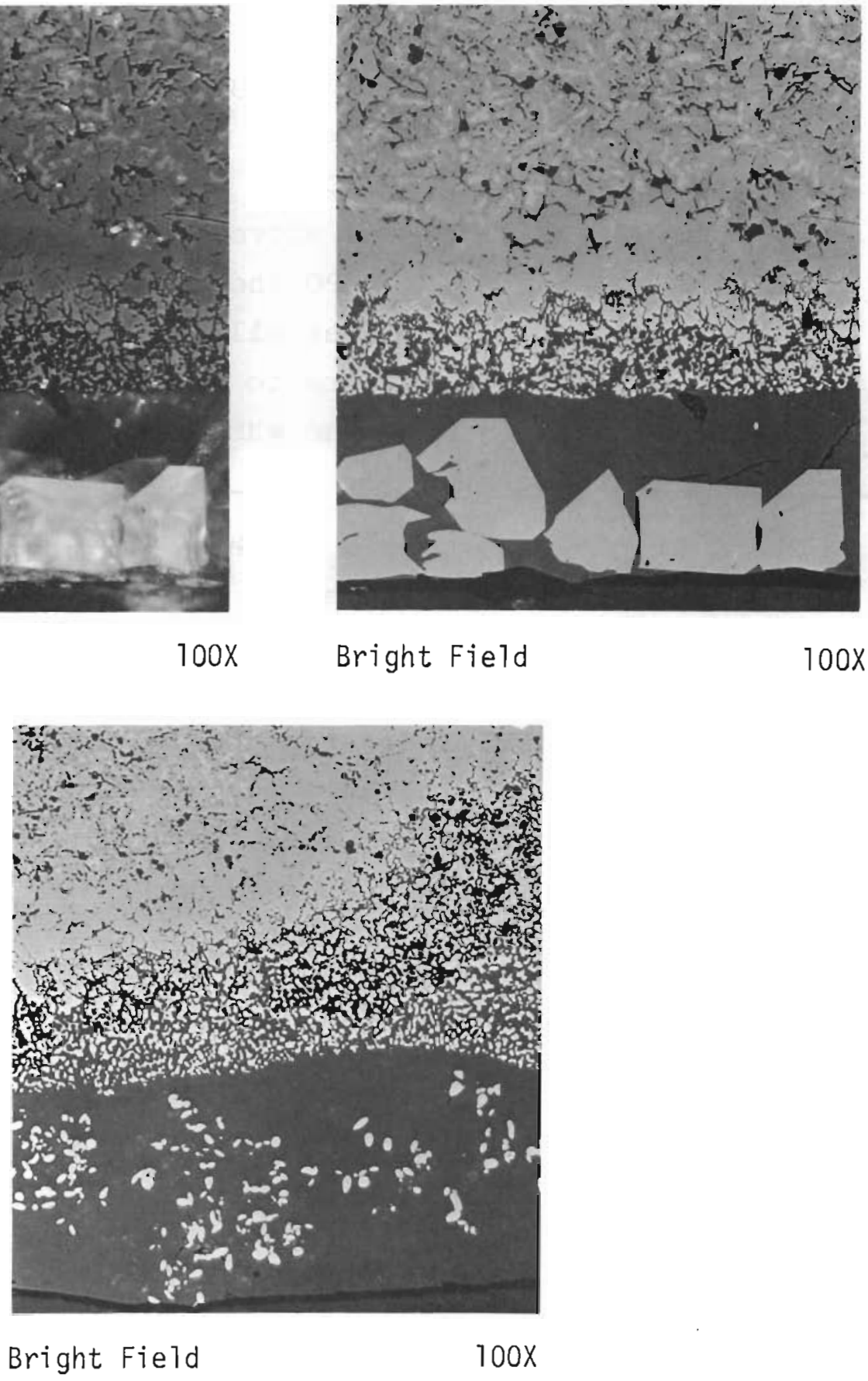

FIGURE 2. Microstructure of Fused Cast $60 \% \mathrm{Al}_{2} \mathrm{O}_{3}$, $27 \% \mathrm{Cr}_{2} \mathrm{O}_{3}$ Exposed to Molten Glass in Air for 108 Hours (Interface Cross Section) 
1. A sample was heated in vacuum at temperatures up to $1100^{\circ} \mathrm{C}$ in a Knudsen cell and the vapor was analyzed by a time-of-flight mass spectrometer. Water and nitrogen oxides came off at temperatures as low as $300^{\circ} \mathrm{C}$ and were mostly gone by $500^{\circ} \mathrm{C}$. At $700^{\circ} \mathrm{C}$ and above, some oxygen came off and near $900^{\circ} \mathrm{C}, \mathrm{PO}$ and $\mathrm{PO}_{2}$ were observed. By $1100^{\circ} \mathrm{C}$, no vapor at all was detected. The reason for the failure to observe at least some of the elements in the waste at this temperature is not understood at this time.

2. A 0.4600 gram sample was heated at $925^{\circ} \mathrm{C}$ for 28 hours in flowing argon and the vapor deposited on a cold finger. The weight loss was 0.0121 gram. $\mathrm{X}$-ray fluorescence analysis of the black sooty vapor deposit indicated the following elements to be present in the roughly quantitative categories listed.

\begin{tabular}{ccc}
$\begin{array}{c}\text { Major } \\
\text { Constituent }\end{array}$ & $\begin{array}{c}\text { Moderate } \\
\text { Constituent }\end{array}$ & $\begin{array}{c}\text { Minor } \\
\text { Constituent }\end{array}$ \\
\cline { 2 - 3 } & $\mathrm{Fe}$ & $\mathrm{Co}$ \\
$\mathrm{Sr}$ & $\mathrm{Mo}$ & $\mathrm{Ni}$ \\
$\mathrm{Zr}$ & $\mathrm{Ba}$ & $\mathrm{Te}$ \\
& $\mathrm{La}$ & $\mathrm{Y}$ \\
& $\mathrm{Nd}$ & $\mathrm{Ce}$ \\
& $\mathrm{Sm}$ \\
& $\mathrm{Gd}$
\end{tabular}

Elements present in the waste but not detected in the $\mathrm{X}$-ray fluorescence analysis, which does not detect elements with atomic numbers less than sodium, were $\mathrm{K}, \mathrm{Cr}, \mathrm{Ag}, \mathrm{Cd}$, and $\mathrm{Pr}$. The sooty 
deposit was very easily removed from the cold finger by light brushing indicating that this material would be very readily airborne.

The fluid bed calcine waste Run $\mathrm{PW}-4 \mathrm{~b}-5$ contains no cesium nor some of the precious metals. A calcine waste has been prepared which does contain these elements and future work will be done with this new material.

Following the exploratory measurements, some equipment modifications were initiated to allow future runs to be much more routine. These will give us the capability of heating samples in a platinum crucible in a stream of dry air at temperatures up to $1500^{\circ} \mathrm{C}$ and measuring the weight loss with a recording balance capable of detecting weight changes of v0.5 milligrams. Simultaneously, the vapor will be deposited on a water-cooled cold finger which can then be analyzed by $\mathrm{X}$-ray fluorescence.

Some effort will be made to try to detect some of the heavier elements with the time-of-flight mass spectrometer but a higher priority will be placed on the other types of measurements.

\section{ENGINEERING STUDIES}

Developmental Spray Calciner and Inconel Melter - W. F. Bonner

Both $\mathrm{PW}-4 \mathrm{~b}$ and $\mathrm{PW}-6$ waste compositions have been successfully solidified into borosilicate glass in the nonradioactive developmental spray solidifier. Calciner wall scaling was minimal and off-gas filter differential pressure remained low. Glass formation and discharge from the melter proceeded smoothly at melt temperatures ranging from 1050 to $1175^{\circ} \mathrm{C}$.

Five runs have been completed. In addition to gaining data on the spray solidification system the purpose of the first two runs was to shakedown the equipment and to gain 
operating experience. During Run DSS-1, water was fed at rates up to 13 liters $/ \mathrm{hr}$ into the calciner maintained at $700^{\circ} \mathrm{C}$. Run DSS-2 tested the entire system with full strength $\mathrm{PW}-4 \mathrm{~b}$ waste.

Run DSS- 3 continued use of $\mathrm{PW}-4 \mathrm{~b}$ feed at a feed rate of 16 liters/hr, and a slightly higher melter temperature.

The purpose of Run DSS-4 was to determine melter characteristics (melt temperature, surface temperature, drain rate, and convective agitation) at melter temperatures of 1150 and $1200^{\circ} \mathrm{C}$. Wall-scaling and off-gas filter performance were also investigated.

Run DSS-5 was the first run in which the high sodium, PW-6, waste composition was solidified. Calciner performance at a feed rate of 9.2 liters/hr was investigated as well as off-gas filter performance and melt characteristics.

The following discussion of the waste processing is organized by solidification equipment component. A detailed description of the spray solidification equipment was presented previously.* (See Figure 3 for a simplified process flow diagram.) Operating parameters and run data for the runs completed to date are presented in Table 3.

\section{Feed System}

Runs DSS-2 through DSS-4 solidified the PW-4b waste composition. The $\mathrm{PW}-4 \mathrm{~b}$ waste is milky grey in color and contains about $4 \%$ solids. PW-6 waste, used in DSS-5, is about the same color but contains almost $6 \%$ solids. The milky solids slowly settle leaving a green supernate.

While processing $\mathrm{PW}-4 \mathrm{~b}$ waste the automatically controlled feed to the calciner normally varied by less than 1 liter/min.

\footnotetext{
* Quarterly Progress Report, BNWL 1761, July 1973.
} 


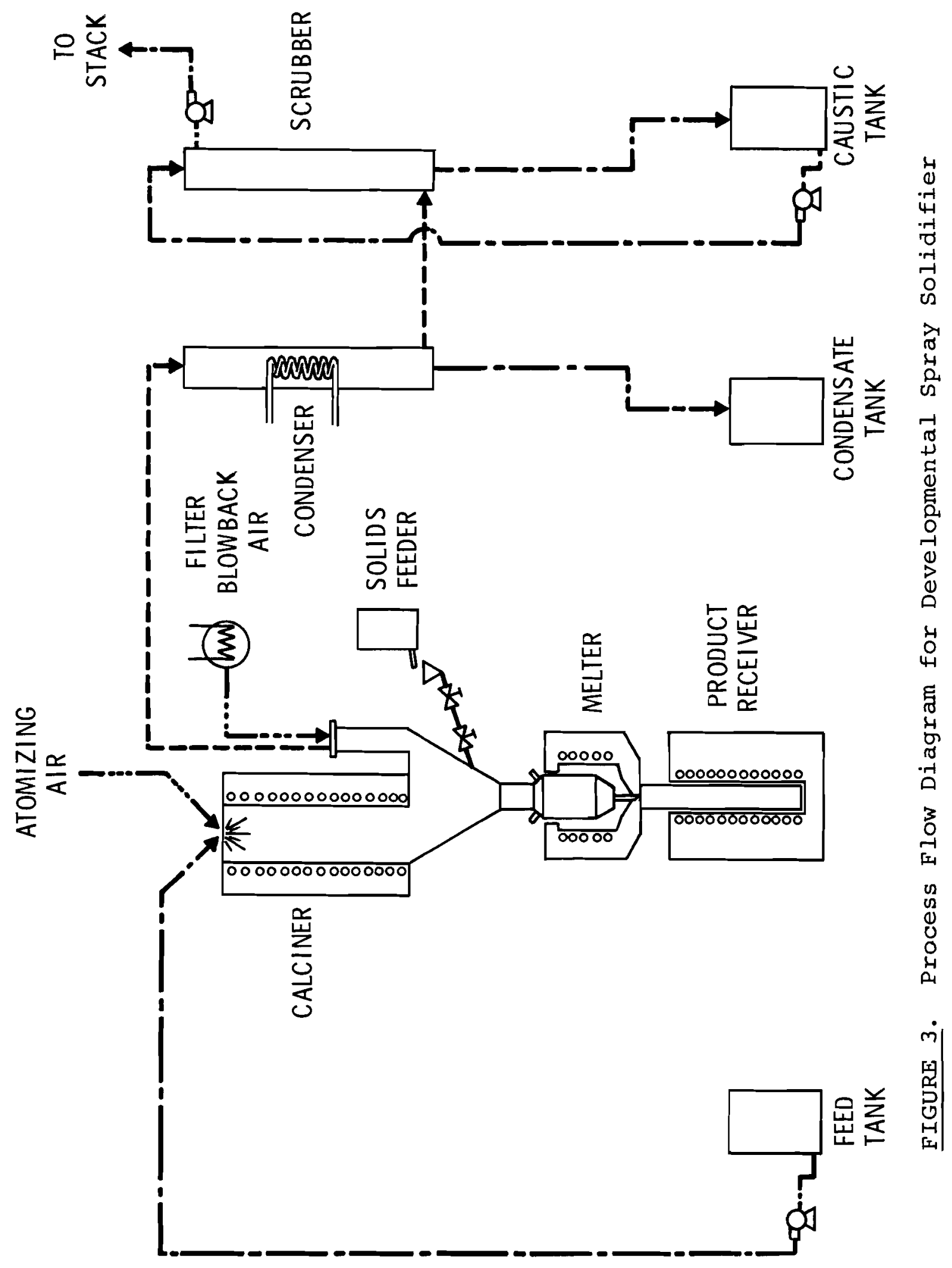


TABLE 3. Operating Parameters and Results of Development Spray Solidification Runs DSS-1 through DSS-5

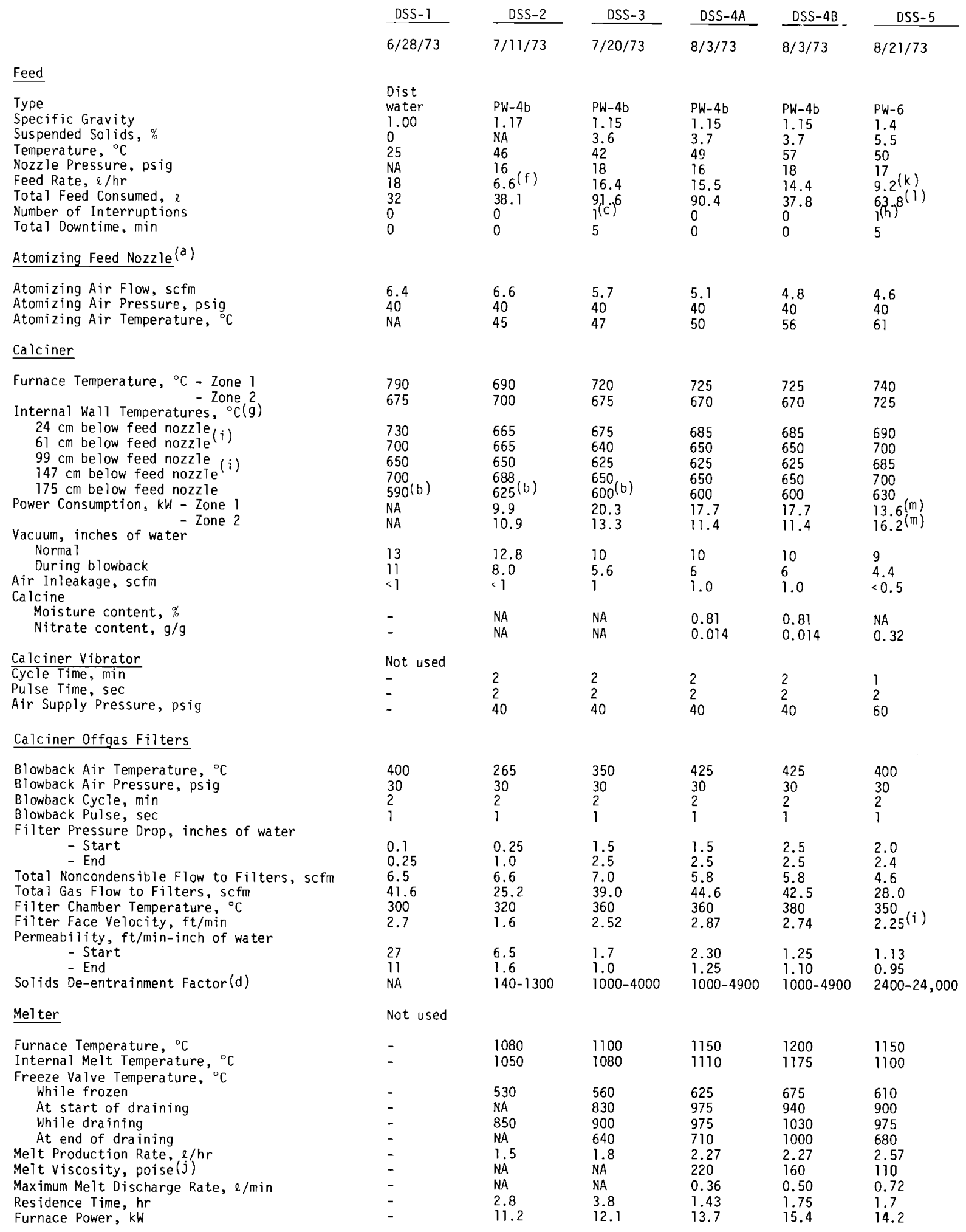




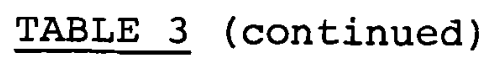

Run Number

Product

Weight, $\mathrm{kg}$

Volume, \&

Bulk Density, $\mathrm{g} / \mathrm{cm}^{3}$

Feed-to-Product Volume Ratio

Equivalent Waste, tonne

Calcine Content of Product, \%

Solids Addition

Additive ${ }^{(e)}$

Frit Size, mesh

Batch size, $g$

Addition Rate, $\mathrm{kg} / \mathrm{hr}$

Total Added, kg

Feeder Type

Condenser

Bottoms, $\mathrm{M} \mathrm{HNO}_{3}$ - Start

Accumulation Rate, $\ell / \mathrm{hr}$

Tota? Accumulation, $\ell$

Scrubber

Circulation Rate, $\ell / m i n$

Bottoms, $\underline{M} \mathrm{NaOH}$ - Start

Accumulation - End

te, $l / h r$

Total Accumulation, $\&$

\begin{tabular}{|c|c|c|c|c|c|}
\hline DSS-1 & DSS-2 & DSS-3 & DSS-4A & DSS-4B & DSS-5 \\
\hline None & & & & & \\
\hline $\begin{array}{l}- \\
- \\
- \\
- \\
-\end{array}$ & $\begin{array}{l}25.6 \\
8.3 \\
3.09 \\
4.5 \\
0.10 \\
13\end{array}$ & $\begin{array}{l}31.2 \\
10.0 \\
313 \\
8.95 \\
0.24 \\
24\end{array}$ & $\begin{array}{l}38.6 \\
12.2 \\
3.16 \\
6.26 \\
0.24 \\
22.3\end{array}$ & $\begin{array}{l}23.8 \\
7.5 \\
3.16 \\
6.26 \\
0.10 \\
22.3\end{array}$ & $\begin{array}{l}54.0 \\
17.0 \\
3.17 \\
3.54 \\
0.17 \\
22.5\end{array}$ \\
\hline $\begin{array}{l}\text { None } \\
- \\
- \\
- \\
-\end{array}$ & $\begin{array}{l}\text { Frit } 73-1 \\
6 \text { to } 20 \\
19.3 \\
4.3 \\
24.2 \\
\text { Slide } \\
\text { valve }\end{array}$ & $\begin{array}{l}\text { Frit } 73-1 \\
6 \text { to } 20 \\
18.2 \\
5.2 \\
28.1 \\
\text { Slide } \\
\text { valve }\end{array}$ & $\begin{array}{l}\text { Frit } 73-1 \\
6 \text { to } 20 \\
96 \\
5.75 \\
37.1 \\
\text { Screw \& } \\
\text { air lock }\end{array}$ & $\begin{array}{l}\text { Frit } 73-1 \\
6 \text { to } 20 \\
96 \\
5.75 \\
15.1 \\
\text { Screw \& } \\
\text { air lock }\end{array}$ & $\begin{array}{l}\text { Frit } 73-1 \\
6 \text { to } 20 \\
100 \\
6.00 \\
42.0 \\
\text { Screw \& } \\
\text { air lock }\end{array}$ \\
\hline $\begin{array}{l}0 \\
0\end{array}$ & $\begin{array}{l}0.0 \\
0.28\end{array}$ & $\begin{array}{l}0.01 \\
0.41\end{array}$ & $\begin{array}{l}0.02 \\
\text { NA }\end{array}$ & $\begin{array}{l}\text { NA } \\
0.84\end{array}$ & $\begin{array}{l}0.20 \\
1.07\end{array}$ \\
\hline $\begin{array}{l}\text { NA } \\
32.0\end{array}$ & $\begin{array}{l}6.5 \\
46.7\end{array}$ & $\begin{array}{l}15.2 \\
84.9\end{array}$ & $\begin{array}{l}12.2 \\
06.6\end{array}$ & $\begin{array}{l}12.2 \\
40.6\end{array}$ & $\begin{array}{l}8.9 \\
56.6\end{array}$ \\
\hline $\begin{array}{l}23 \\
0 \\
0 \\
\text { NA } \\
\text { NA }\end{array}$ & $\begin{array}{l}10.3 \\
\mathrm{NA} \\
\mathrm{NA} \\
0.25 \\
.52\end{array}$ & $\begin{array}{l}10.3 \\
6.4 \\
5.5 \\
N A \\
N A\end{array}$ & $\begin{array}{l}10.3 \\
5.61 \\
\mathrm{NA} \\
0.18 \\
1.3\end{array}$ & $\begin{array}{l}10.3 \\
\text { NA } \\
4.29 \\
0.18 \\
0.6\end{array}$ & $\begin{array}{l}10.3 \\
4.02 \\
1.44 \\
0.5 \\
3.9\end{array}$ \\
\hline
\end{tabular}

$N A=$ Not available.

(a) External mix pneumatic atomizing nozzle - Spraying Systems Co., Setup \#42

(b) An after-run inspection showed this thermocouple had broken loose from wall.

(c) Leakage around the spray nozzle cleanout needle required switching to water feed for tightening.

(d) Based on analyses of $\mathrm{K}, \mathrm{Cr}$, and $\mathrm{Ni}$

(e) Composition reported in BNWL-174T

(f) Calculated from condensate accumulation since pump seal leaked

(g) Used to control calciner furnace output

(h) Feed interruption due to loss of melting furnace control was caused by a failed thermocouple.

(i) Only 12 of the 15 filter elements were usable due to a failure in a blowback solenoid valve.

(j) Calcuiated from the Hagen-Poiseville Law

(k) Last 2 hours of the run was at 5 liters/hr, data not included

(1) Includes data at 5 liters $/ \mathrm{hr}$ feed rate

(m) Greater power consumption in zone 2 due to the calciner wall of zone 1 being partially insulated by the scale 
Several times during the runs, however, the flow rate spiked much higher, apparently due to solids momentarily lodging in the control valve, resulting in controller action. In addition, some feed nozzle plugging problems were encountered while processing $\mathrm{PW}-6$, requiring use of the nozzle cleanout needle. These process upsets produced no observable ill effects in any other part of the system.

A magnetic flowmeter with a 1/10-inch flow tube is used to measure and control feed flow to the calciner. A 20-mesh strainer upstream of the flowmeter protects against flowmeter plugging. No plugging problems have been experienced with the magnetic flowmeter or the strainer. However, many pieces of scale and foreign articles large enough to plug the flowmeter and/or spray nozzle have been removed from the strainer.

During DSS-2 the seal in the feed pump began leaking after about 4 hours of operation. It was later determined that the failure was due to misaligned seal faces.

\section{Spray Calciner}

Calciner operation was very smooth throughout the five runs. Calciner vacuum was easily maintained and minimal wall scaling was observed.

Calcine from the spray calciner was analyzed to determine calciner efficiency. Moisture content was less than $1 \%$ and, during DSS-5, $32 \%$ of the $\mathrm{NaNO}_{3}$ was decomposed in the calciner. Calcine samples from $\mathrm{PW}-4 \mathrm{~b}$ feed were rust-brown colored and about the consistency of talcum powder while PW- 6 calcine was about the same color but more cohesive and less dusty.

During DSS-1 a large calciner wall temperature change was noted when the feed rate was changed. To minimize this, furnace control was changed from thermocouples inside the furnace to 
thermocouples welded inside the calciner. High temperature alarms and automatic shutoffs, however, are still activated by thermocouples in the furnace itself.

Before operations began, the calciner interior was sandblasted in preparation for ultrasonic thickness testing. After DSS-1 and DSS-2 the upper $178 \mathrm{~cm}$ of the drying chamber still appeared sandblasted and, after DSS-3, only a thin calcine coating ( $1 \mathrm{~mm}$ ) was observed over a 1/4-meter diameter spot on the calciner wall. A small amount of calcine deposition around the spray nozzle was observed following DSS-2. Following DSS-3 a skirt of calcine $3 \mathrm{~mm}$ long by $10 \mathrm{~mm}$ OD with $1 \mathrm{~mm}$ walls had developed around the nozzle tip. It is probable that the spot of wall deposition observed following DSS-3 was a result of irregular flow patterns caused by uneven nozzle deposition. Signs of abrasion on the nozzle tip are not observed. Following DSS-4 the spot of scale observed previously on the calciner wall had grown to about $1 / 2$ meter diameter. The atomizing nozzle was subsequently removed, inspected and then operated in a transparent calciner mockup, but no significant irregularities in the nozzle or spray pattern were observed.

Calcination of PW-6 waste in DSS-5 produced a 1 to $2 \mathrm{~mm}$ thick deposit on the upper half of the calciner interior. This was not surprising since both sodium and nitrate ions are present in large amounts in $\mathrm{PW}-6$, and $\mathrm{NaNO}_{3}$ melts at $307^{\circ} \mathrm{C}$. The small amount of scaling was therefore somewhat unexpected, as well as the fact that the calciner furnace temperatures indicated that the scale buildup reached a dynamic equilibrium after 2 hours run time and little change occurred during the last 6 hours of the run. (Subsequently a 48-hour run, DSS-6, was made with the PW- 6 waste and very little wall scaling was again apparent.) 
BNWL -1788

\section{Calciner Off-gas Filters}

The off-gas filters are highly efficient in removing solids from the calciner vapors. Their efficiency has increased since a coating of calcine was established on the filters. During DSS-4 and DSS-5 the solids de-entrainment factors for various feed constituents ranged from 1,000 to 24,000, while during DSS-2 the de-entrainment factors were 140 to 1,300 .

The filter differential pressure remained at or less than 2.5 inches of water during the runs and appears to have reached a maximum. Longer runs are planned to determine whether significant additional filter pressure drop will develop in time.

Following DSS-2, DSS-4, and DSS-5 the filters were inspected and found to be coated with a thin layer of purplebrown calcine. Inspection following DSS-3 showed similar coatings on all but the three south end filters. Each of these had a coating of calcine about $1 / 8$ inch thick over the entire element. Investigation showed that the solenoid valve in the blowback air piping to these three elements was defective and application of a burst of 60 psi blowback air effectively removed the caked calcine.

\section{Solids Feeder}

The recently developed slide valve solids feeder described previously* was used for frit addition to the melter during DSS-2 and DSS-3. The feed rate was accurate to within $10 \%$ of the set point. Since feed is on a volumetric basis the accuracy is limited to the reproducibility of the frit bulk density but can be improved by feed hopper vibration.

After over 100 hours of operation the 304L stainless steel feeder was disassembled and inspected. At points where frit is sheared by feeder action the stainless steel was worn as much as $1 / 16$ inch. Sharp edges were curled and all other surfaces

* Quarterly Progress Report, BNWL-1741, Apri1 1973. 
forcibly scraped by the frit were abraded about $1 / 32$ inch. Thus, a hardened tool steel feeder has been fabricated incorporating several design improvements and is undergoing testing.

Frit was added to the melter during DSS-4 and DSS-5 with a screw feeder and air lock assembly. With this type feeder, frit metered from a hopper by a screw feeder drops through a funnel into a section of pipe containing two air operated ball valves. The valves operating simultaneously act as an air lock so that solids can be added without disrupting the calciner vacuum.

Rate checks were made during the runs to observe and, if necessary, correct the frit flow rate. At operating conditions the maximum feed rate variation from set point was $7 \%$ and with hourly rate checks and adjustments the feed rate could be kept within $2 \%$ of the set point.

\section{Melter}

The melter and furnace operated smoothly throughout the runs. The furnace temperature at the control point varied by less than $10^{\circ} \mathrm{C}$. The upper third of the furnace operated from 20 to $40^{\circ} \mathrm{C}$ cooler than the set point, being cooler when the melt level was high in the melter.

Operation at a melter furnace temperature of $1100^{\circ} \mathrm{C}$ during DSS- 2 and DSS- 3 resulted in melt temperatures of 1050 to $1080^{\circ} \mathrm{C}$ at which temperature the melt was viscous and no agitation was observed. Frit and calcine would lay on the melt surface, then slowly melt. The melt surface was about $100^{\circ} \mathrm{C}$ cooler than the melt while the level was low and cooled further as the melt depth increased. At a depth of $23 \mathrm{~cm}$ the surface was $500^{\circ} \mathrm{C}$ cooler than the melt and was covered with an estimated 0.75 inch of calcine and frit. 
Operating the melter at 1100 to $1175^{\circ} \mathrm{C}$ produced a free flowing, nearly homogeneous melt. Processing of $\mathrm{PW}-4 \mathrm{~b}$ waste at $1100^{\circ} \mathrm{C}$ produced melt containing large numbers of inclusions throughout. At $1175^{\circ} \mathrm{C}$ the only inclusions observed were in the last $10 \%$ of the melt drained. Since the density of the inclusion material, about $3.5 \mathrm{~g} / \mathrm{cm}^{3}$, is slightly greater than the glass, its existence is believed to be due to poor mixing in the melter. A sparger and mixer are being prepared for investigation during the next run.

Dumping the melter was accomplished by cutting off the cooling air to the freeze valve coil. When this was done the valve thawed in 6 to 8 minutes when the temperature reached about $830^{\circ} \mathrm{C}$. Due to the high melt viscosity, draining the melter required $1 / 2$ to 1 hour. Once the melt level was low the freeze valve sealed about 5 minutes after the cooling air was resupplied. Attempts to seal the freeze valve before the melter was nearly empty were not successful.

Melt viscosity, as calculated from the melt drain rate, decreased 60 poise with a temperature increase of $65^{\circ} \mathrm{C}$. The lower viscosity promoted better melt homogeniety, and faster, more complete melt draining.

Large amounts of fumes evolving from the melter while processing $\mathrm{PW}-6$ waste gave the melt the appearance of boiling. With a calciner feed rate of 10 liters/hr the calcine and frit falling into the melter formed a relatively cool surface layer.

The melt level was monitored by four thermocouples in ceramic thermowells at various levels in the melter. No problems were encountered during DSS-1 and DSS-2, but during DSS-3 it was observed that the thermowells were broken. Since the thermowell tips were frozen in the glass following DSS-2, it is probable that the thermal stresses of melter cooling and reheating caused 
the fractures. The chromel-alumel thermocouples nevertheless continued to function properly although immersed in the melt throughout the run.

During runs in which the melt surface was relatively cool the melt level was easily and accurately determined by observing the melter internal temperatures. Recorded internal temperatures reached a minimum as the cool melt surface rose past the thermocouple. However, with the melt surface about the same temperature as the melt, as observed in Run DSS-5, melt level determination based on temperature was not accurate.

Routine inspection of the melter following Runs DSS-2, DSS-3, and DSS-4 revealed a relatively clean melter with solidified product covering less than $1 / 4$ of the melter interior. However, following DSS-5, wherein PW-6 waste was first processed, the walls were completely covered with an irregular glass scale, about 1 to $3 \mathrm{~mm}$ thick.

\section{$\underline{\text { Product }}$}

The solidified product is irregular in color and texture, varying from milky green or brown to black and from a glassy to ceramic texture. During DSS-2 the frit-to-calcine ratio was high resulting in a dark green translucent glass. More accurate feed rates during DSS-3 produced a dark green, much more opaque product. Solidification of PW- 6 feed in DSS-5 produced an extremely dark green almost black glass. Scattered widely throughout all the product are purple-grey inclusions usually about $1 / 8$ inch wide by $1 / 4$ inch long. They are estimated to normally occupy less than $0.1 \%$ of the total volume.

At melt temperatures over $1100^{\circ} \mathrm{C}$ the product receiver filled uniformly with only a 2 to $3 \mathrm{~cm}$ stalagmite forming during the last minutes of draining. At temperatures less than $100^{\circ} \mathrm{C}$ the receiver filled unevenly and tall stalagmites formed due to the slow melt discharge rate. 
A small amount of fine glass fibers were observed in the product container and vent piping. They apparently formed as the molten glass fell through the air, then struck the cooler product in the receiving drum.

The surface of the final PW- 6 waste product was covered with an estimated 300 grams of bright yellow compound identified as impure $\mathrm{Na}_{2} \mathrm{MOO}_{4}$.

\section{Auxiliary Equipment}

Filtered off-gas is routed through a condenser and a caustic scrubber before being discharged. Both units operated satisfactorily with about $90 \%$ of the $\mathrm{HNO}_{3}$ being recovered in the condenser and the remainder in the scrubber.

Wiped Film Evaporator - R. D. Dierks and B. O. Kahle

A horizontal, wiped-film evaporator has been installed in EDL-102 to evaluate the possibilities of using a wiped-film evaporator to concentrate a wide range of liquid wastes and to feed a slurry product into a direct coupled, continuous melter. Two runs, one using a demineralized water feed (WFE-0) and the other using a nonradioactive, simulated $\mathrm{PW}-4 \mathrm{~b}$ feed (WFE-1) have been completed, exercising the system and probing the characteristics of the evaporator.

The evaporator that has been installed for these studies was designed by the Kontro Company and built by Artisan Industries in 1964. It is a horizontally positioned, truncated cone-shaped drum with a $2^{\circ}$ taper, about 1 foot in diameter and about 3 feet long. A rotor shaft, fitted with four fixed paddles, extends through the closed ends of the drum, and is driven at selected speeds from 300 to $600 \mathrm{rpm}$. The paddles are axially positioned on the rotor shaft and are adjustable to give a clearance of from $1 / 16$ to $1 / 32$ inch between the paddle blades and the drum wall. 
The evaporator has approximately 5 square feet of steamjacketed heat exchange surface. Feed enters the large diameter end of the drum and is wiped in a thin film around the heated inside surface of the drum by the rotor paddles. Heat transfer to this highly agitated thin film is excellent, ranging from 340 to $450 \mathrm{Btu} / \mathrm{hr}-\mathrm{ft} \mathrm{t}^{2}{ }^{\circ} \mathrm{F}$ (based on the temperature difference between the jacket steam and boiling water) for a demineralized water feed at various operating conditions. Heat transfer coefficients for the equipment using simulated $\mathrm{PW}-4 \mathrm{~b}$ feed in Run WFE-1 ranged from 175 to $250 \mathrm{Btu} / \mathrm{hr}-\mathrm{ft}{ }^{2}{ }^{\circ} \mathrm{F}$.

The concentrate discharges by gravity from the evaporator through a 3-inch nozzle penetrating the underside of the drum at the small diameter end. During WFE-l, the simulated PW-4b feed was reduced to a smooth paste with a consistency varying from that of heavy cream to that of mayonnaise, and discharged without difficulty to a concentrate receiver positioned directly under the evaporator. The evaporator was operated at several sets of conditions covering rotor speeds from 300 to $600 \mathrm{rpm}$, rotor clearances from $1 / 16$ to $1 / 32$ inch, jacket steam pressures from 30 to $70 \mathrm{psig}$, and feed rates from 55 to 80 liter/hr. The degree of concentration and solids carryover into the off-gas system effected by these various operating conditions have not yet been determined.

Additional runs, using other simulated waste feeds and more rigorous operating conditions, will probe the capabilities of the evaporator for its optimum capacity and concentrate quality and for its flexability for a variety of feed materials. 
Fluidized Bed Calcination Studies - L. L. Taylor (Allied Chemical Corporation). This work was carried out by Allied Chemical Corporation, Idaho Chemical Programs, in support of the Waste Fixation Program.

Nonradioactive Pilot Plant

Installation of the 6-inch diameter pilot plant calciner has been completed; checkout and base line aluminum nitrate runs are scheduled. Any necessary modifications will be completed after checkout. $\quad \mathrm{PW}-4 \mathrm{~b}$ studies are planned to verify the suitability of the off-gas cleanup system recommended for the PNL calciner.

Attempts to calcine the high sodium PW-6 waste within the constraints supplied by PNL (no additives which have severe adverse effects on melt processing or product quality) have almost exhausted available options. Efforts are being directed toward dilution of the sodium concentration with feed additives that provide a suitable calcine matrix.

\section{Design Criteria for the Radioactive Demonstration}

\section{Fluidized Bed Calciner}

Two significant changes in the design criteria are being considered. The preliminary design crıteria were based on a cylindrical calciner (8-inch diameter). However, remote operation and maintenance may be simplified by a calciner of square cross section with a removable side panel.

In-bed combustion was originally recommended as the primary means of process heating. Calculations indicate that electrically heated finned tubes located in the fluidized bed may be capable of supplying adequate heat for calcining up to 15 liters/hr of $\mathrm{PW}-4 \mathrm{~b}$ waste at $500^{\circ} \mathrm{C}$. Electrical heating will remain as an option at this time, as its feasibility has not been demonstrated in the pilot-plant calciner. 
Direct-Coupling Induction Melter - R. B. Dakan

The possibility of melting glass in an induction furnace via direct coupling with the glass has been investigated. Computer calculations* for ceramic melters of $1 / 10,1 / 2,1$ and 3 ton/day melt forming capacities show that direct coupling is, in theory, possible with any of these sizes. Due to potential problems arising from coupling with the melter insulation at high voltages ( $\geq 7000$ volts) the $1 / 10$ ton/day melter appears to most warrant further investigations because of its lower voltage requirement (1000 volts) and small coil spacing ( 1 turn/inch). A $1 / 10$ ton/day melter operating on a continuous 24-hour basis has a volume of $0.2 \mathrm{ft}^{3}$ and a power requirement of 3 or $4 \mathrm{kw}$.

* G. Jansen, Jr., Design of Induction Heating Coils for Cylindrical Charges, HW-74093, General Electric Company, Richland, Washington, July 16,1962 . 


\section{AEC WASTE SOLIDIFICATION}

\section{ELECTRIC GLASS TANKS - J. D. Kaser}

Discussions have been held with glass industry representatives concerning the design and construction of electric glass melters for the vitrification of high-level radioactive waste. The heat for melting is supplied by passing an electric current through the molten glass.

Electric glass melters have the advantages of low off-gas generation (compared to gas-fired melters) and a cool surface covered with unmelted feed material which should minimize the evolution of volatile fission products. Other advantages of these melters are the high local temperatures in the molten glass and convection currents which promote the formation of a homogenous product. Furthermore, the internal heating allows cool wall temperatures which provide for more reliable containment and long melter life. Finally, these melters can be readily scaled up for the large throughput capacities necessary for processing the large volumes of AEC waste.

Plans are also being made for melting tests in a small electric melter or glass tank in an in lustrial pilot facility using inactive simulated wastes. These tests will be aimed at proving feasibility and obtaining data to aid the design of prototype melters for high-level wastes. Specifically, information will be sought on off-gas volume and composition, operating temperature of the ceramic lining, startup without flames or burners, product quality, effects of moisture in the feed material, and throughput capacity.

MOLYBDENUM ELECTRODE GLASS-MELTING FURNACE - R. B. Dakan A laboratory-scale molybdenum electrode glass melter has been constructed to gain first-hand experience in the design 
and operation of electric glass melters. The melter has a 9- x 9- x 6-inch cavity and is designed for a maximum operating temperature of about $1400^{\circ} \mathrm{C}$. Heat is generated by passing an electrical current through the molten glass between the molybdenum electrodes. Separation of the electrode tips can be varied from approximately 3 to 8 inches to observe the operating characteristics of the furnace. 


\section{RADIOACTIVE DEMONSTRATIONS}

RADIOACTIVE WASTE FOR WFP DEMONSTRATION RUNS - D. H. Siemens

Part of the radioactive waste that is required for the WFP demonstration runs will be obtained from a commercial reprocessor's calcined high-level waste. This waste, in the reprocessor's canister, will be shipped to the Pacific Northwest Laboratory (PNL) in a privately owned, shielded cask.

On arrival of the cask at PNL, the canister containing the waste will be removed from the cask and transferred into the Solidification Cell (B-Cell) of the 324 Building. Access to the calcine will be made by mechanically removing a weld that secures the final closure of the canister, thereby allowing the closure to be unthreaded from the neck of the canister. A valved and flanged adaptor will then be installed on the neck of the canister to facilitate transferring the calcine to a vessel for dissolution.

Design of equipment required to remove the canister from the cask, removal of the waste from the canister, and subsequent dissolution of the waste is complete and the equipment is presently being fabricated. 


\section{PRODUCT CHARACTERIZATION}

\section{INTERIM STORAGE OF WSEP CANISTERS}

Measurements on Core-Drilled Samples - J. E. Mendel

The SS-13 canister of WSEP in-pot melting borosilicate glass was core drilled in three locations: 10, 30, and 55 inches from the bottom. This completes sampling of all three canisters of WSEP borosilicate glass during FY 1973. These samples are the first that have been taken from ss-13, which has been stored in water almost continuously since it was filled July 28, 1970. The core sampling was done with the high-speed water-cooled drill and, as is usual for the glassy products, the samples were obtained as many relatively small chunks. The SS-13 samples were less glassy than those from ss-12, a canister of the same nominal composition.

Leach test results obtained on the core sample taken at the 30-inch level are shown in Table 4. The initial leach rates were a factor of 3 to 6 higher than those obtained on samples of SS-12, the other WSEP in-pot melting borosilicate glass product; however, within 6 weeks the leach rate had decreased to a comparable value. The higher initial leach rate is probably due to the less glassy nature of the ss-13 product.

TABLE 4. Leachability of WSEP In-Pot Melting Borosilicate Glass Product after 2.8 Years Storage at Approximately $60^{\circ} \mathrm{C}$ Wall Temperature

\begin{tabular}{|c|c|c|}
\hline \multirow[b]{2}{*}{$\begin{array}{c}\text { Test } \\
\text { Duration } \\
\end{array}$} & \multicolumn{2}{|c|}{$\begin{array}{l}\text { Leach Rate in Distilled water } \\
\text { at } 25^{\circ} \mathrm{C} \text {, grams glass } / \mathrm{cm}^{2} \text {-day } \\
\text { (based on } 137 \mathrm{Cs} \text { in leachate) }\end{array}$} \\
\hline & $\begin{array}{l}\text { Sample from } \\
\text { Near Wall of } \\
\text { Canister } \\
\end{array}$ & $\begin{array}{l}\text { Sample from } \\
\text { Near Centerline } \\
\text { of Canister } \\
\end{array}$ \\
\hline 1 day & $3.3 \times 10^{-4}$ & $3.5 \times 10^{-4}$ \\
\hline 1 week & $7.8 \times 10^{-5}$ & $1.3 \times 10^{-4}$ \\
\hline 3 weeks & $5.3 \times 10^{-5}$ & $6.5 \times 10^{-5}$ \\
\hline 6 weeks & $3.8 \times 10^{-5}$ & $3.2 \times 10^{-5}$ \\
\hline
\end{tabular}


Thermowell Leaks in WSEP Canisters - J. E. Mendel

As has been described previously, small leaks, associated with the thermowells, have appeared in several of the WSEP waste canisters. A series of tests on SS-12, one of the leaking canisters, and a stress analysis have shown quite conclusively that the leaks are located at the welds where the thermowells enter the canister and that they are due to stress failure rather than corrosion.

The tests on the SS-12 canister included:

- The specially designed eddy-current probe, mentioned in the last quarterly report, was lowered to the bottom of both thermowells. The sensitivity of the probe was shown by strong signals obtained at four points along the centerline thermowell. The location of these signals corresponded to points where the core drill had touched the thermowell. Aside from these mechanicallyproduced flaws, the eddy current probe indicated both thermowells were in excellent condition.

- A sample of the centerline thermowell, core drilled out 12 inches above the bottom of the canister, gave visual corroboration that the thermowell was not corroded.

- The thermowell was filled with water while the canister was under vacuum. The water level dropped to a level corresponding to the top of the thermowell weld in a few minutes and stabilized at that point.

A stress analysis of the thermowell weld area is given in the following section.

Analysis of Thermowell Failures - C. C. Chapman

The WSEP canisters were leak tested routinely to check the quality of the cap weld before being placed in storage. However, several WSEP waste canisters were found to have developed 
small leaks when retested at a later date, 6 months to several years after the first test. With the helium mass spectrometer leak detection system, the leaks were found to be in the canister thermowells, but the location within the thermowells was unknown. Initially, it was believed that localized corrosion was the cause of the thermowell leakage. However, examination of portions of the thermowells obtained by core drilling, did not show any significant sign of corrosion. After several nondestructive tests of the thermowells (see above), the location of the thermowell leaks was determined to be at the junction of the thermowell and the canister wall (see Figure 4).

A review of the thermal history experienced by the canister components indicated that the failure was induced by thermal stresses and augmented by adverse weld conditions. A qualitative explanation of the thermowell failure is given below.

After the canisters were filled with molten glass, they were allowed to cool. As the glass cooled and solidified, the thermowells (immersed in glass away from the canister wall) were frozen in the glass while at a higher average temperature than the canister wall. Up to this point the thermowells were free to expand or contract in the molten glass without thermal stresses. However, after the glass had solidified and constrained the thermowells, any change in the average temperature difference between the thermowell and the wall resulted in thermal stresses. When the canister continued to cool, the thermowells cooled more than the canister wall introducing a tensile load in the thermowells. When the initial leak tests were taken, thermal stresses existed in the thermowells $(\sim 30,000$ psi) but were not sufficient to cause failure. While the canisters were in interim storage, the amount of decay heat decreased and the glass and the thermowells cooled. This introduced increasing thermal stress ( 60,000 to 90,000 psi) until the thermowell to canister wall junction failed. 


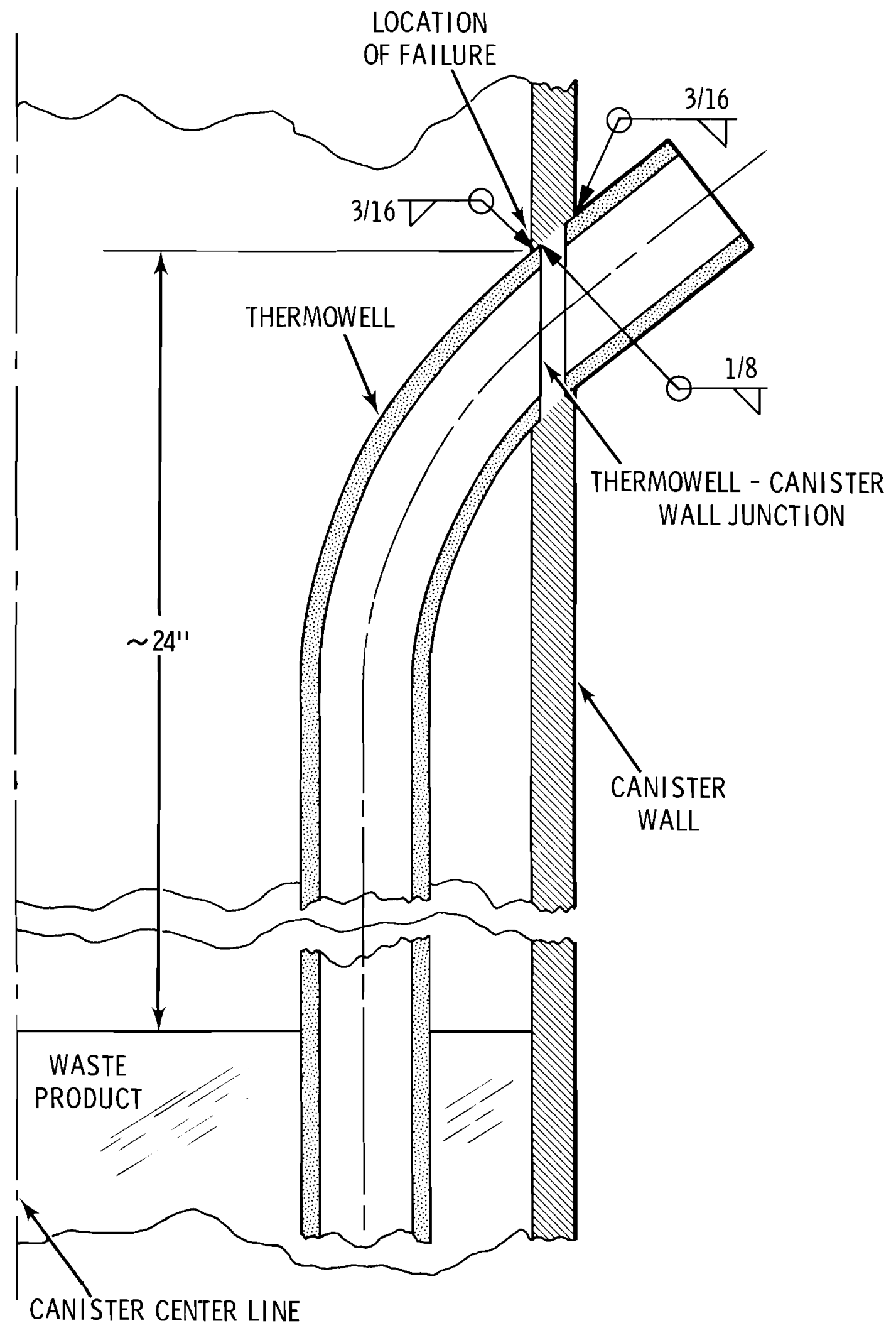

FIGURE 4. Detail of Canister Thermowell Weld 
Although stress levels in the 60,000 to 90,000 psi range are not extremely large, the failure of the junction becomes more convincing when the effect of the three welds are included. In particular, the two filled welds nearest the inner surface of the wall would provide ample opportunity for such adverse phenomena as embrittlement, localized flaws, residual weld stresses, etc. to occur. Munse* reported failures associated with welding occurring at nominal stress levels as low as 20,000 psi. Thus, the induced thermal stresses coupled with the weld design were sufficient to cause failure.

It should be emphasized that the failure occurred in the thermowell to canister wall junction (which would not necessarily be present in production canisters which may not even contain thermowells) and not in the canister wall. However, the observed failures emphasize the importance of considering the influence of thermal stresses and weld design in future canister designs.

HELIUM BUILDUP IN WASTE GLASS - D. F. Newman and D. C. Quimby

A variety of different glass compositions have been investigated to determine their suitability as high-level waste fixation media. The high-level waste generated in the reprocessing of commercial nuclear fuels contains actinide nuclides which decay naturally by alpha particle emission. The emitted alpha particles each capture two electrons near the end of their ionization tracks and are thus converted into neutral helium atoms. This helium is expected to be produced uniformly in the waste glass because the waste calcine containing actinides is distributed uniformly in the glass and the alpha particles have extremely short ranges (about $2 \times 10^{-3} \mathrm{~cm}$ ) in glass. The internal helium gas guildup will result in structural stresses in the waste fixation media due to low solubilities and diffusivities of helium in glasses. To aid in the evaluation of the potential for cracking

* W. H. Munse, "Brittle Fracture in Weldments," in Fracture, an Advanced Treatise, edited by H. Liebowitz, Academic Press, New York, 1969. 
of the fixation media a computer code was developed to calculate the helium density and internal stress at different temperatures as a function of time and position in waste glasses containing alpha emitting materials.

Helium Production Rate

The rate of alpha production within the solid decreases as a complicated function of time due to many isotopes decaying with different half-lives. However, over relatively short periods of time the alpha particle generation rate may be very closely approximated by an exponential decay rate. Alpha particle emission rates evaluated for waste from $\mathrm{LWR} \mathrm{UO}_{2}$ fuel and $\mathrm{LWR} \mathrm{Pu}$ recycle fuel at an exposure of 33,000 $\mathrm{MWd} / \mathrm{MT}$ * were used in this study. The specific volume of the solidified waste was assumed to be $2 \mathrm{ft}^{3}$ per metric ton of fuel reprocessed. During the first 100 years after reprocessing the density of cumulative helium produced in the solidified waste would be $2.1 \times 10^{18}$ and $5.3 \times 10^{19}$ helium atoms $/ \mathrm{cm}^{3}$, for $\mathrm{UO}_{2}$ and $\mathrm{Pu}$ recycle, respectively. Solubility and Diffusivity of Helium in Glass

The solubilities and diffusivities of helium in waste glasses have not been measured. However, some reasonable estimates of these properties can be obtained from the correlation of measured diffusion coefficients and solubilities for sodium silicate glasses** and sodium borosilicate glassest such as that shown in

* D. F. Newman, "Radiation Damage in Borosilicate Glass," BNWL-1741, p. 32, Quarterly Progress Report, Research and Development Activities, Waste Fixation Program, December 1972 through March 1973, Battelle, Pacific Northwest Laboratories, Richland, WA, April 1973.

** J. E. Shelby, "Effect of Phase Separation on Helium Migration in Sodium Silicate Glasses," J. Amer. Ceram. Soc., vol. 56 no. 5, pp. 263-266, 1973.

+ V. O. Altemose, "Effect of Alkali Oxides on the Diffusion of Helium in a Simple Borosilicate Glass," J. Amer. Ceram. Soc., vol. 56, no. 1, pp. 1-4, 1973. 
Figure 5 for $200^{\circ} \mathrm{C}$ data. The addition of $\mathrm{Na}_{2} \mathrm{O}$ to either silicate or borosilicate glass reduced both the solubility and diffusion coefficient for helium. The effect of increasing the amount of $\mathrm{Na}_{2} \mathrm{O}$ in sodium silicate glass, however, is not as great as in sodium borosilicate glasses.* In other words, the effect of packing or stuffing of the glass network by sodium ions is greater for a network containing both silica and boron than for a silica network alone. Adding lithium, potassium, rubidium or cesium oxide to borosilicate glass has much the same effect as sodium in plugging holes or interstices within the glass network. Similarly, the constituents of the waste calcine are expected to reduce the solubility and diffusivity of helium in typical highlevel radioactive waste glasses.

The solubility of helium in glass is only a weak function of temperature, but the helium diffusion coefficient is strongly temperature dependent. However, the height of the glass $(>200 \mathrm{~cm}$ ) in a waste can is so large in comparison to the helium permeation rate that no significant leakage of helium from glass near the bottom of the can occurs, for even the largest diffusion coefficients. The maximum internal stress during the first 100 years of high-level waste can storage is mainly dependent on the helium solubility in glass.

The computer code, HELIUM, ** was developed to provide a calculational tool which can be used to evaluate the linear diffusion of helium from glasses containing alpha emitting radioactive waste. The program will solve one-dimensional diffusion equations for

* V. O. Altemose, "Effect of Alkali Oxides on the Diffusion of Helium in a Simple Borosilicate Glass," J. Amer. Ceram. Soc., vol. 56 , no. 1 , pp. 1-4, 1973.

** D. C. Quimby, HELIUM: A Computer Program for Evaluating Time and Position Dependent Helium Density and Internal Stress in Materials Containing Alpha Emitters, BNWL-B-305, Battelle-Northwest, Richland, WA, September 1973. 


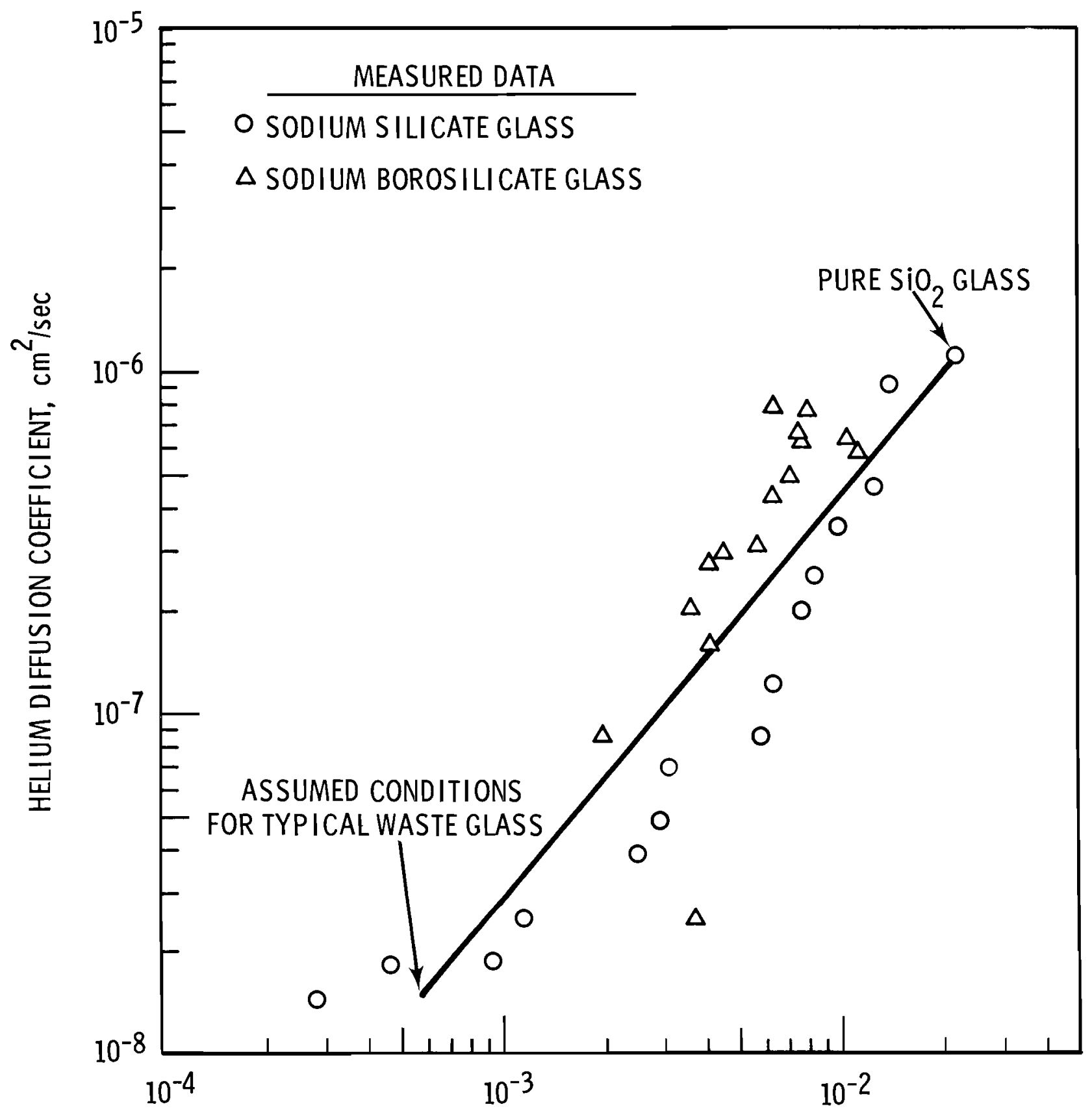

HELIUM SOLUBILITY IN GLASS, He DENSITY IN GLASS/He DENSITY IN GAS

FIGURE 5. Correlation of Diffusion coefficient and Solubility for Helium in Glass at $200^{\circ} \mathrm{C}$ 
either spherical or slab geometries. An important feature of the program is that the region surrounding the solid may be considered to be either a void or a plenum in which the helium gas is trapped.

Mechanical Strength of Glass

Glass is relatively weak in comparison to metals. Its tensile strength is roughly 10 to 15 times less than its compressive strength. Consequently, tensile strain in glass involves far greater risk than compressive strain. In addition, its theoretical tensile strength is about 100 times that measured for sheet glass and over 10 times that measured for fine fibers. It would appear, then, that most glass specimens have only a fraction of their theoretical strength.

A literature study of the breaking strength of glass under tensile stress was made to determine the allowable internal stress for waste glasses. An estimate of the breaking strength for borosilicate glass of about $9300 \mathrm{lb} / \mathrm{in}^{2}$ was obtained from results reported by Elliott* and Stanworth.** The results of experiments on glass to determine the effect of tensile stresses of very long duration, reported by Holland and Turner, $t$ show that there is a marked decrease in stress which the sample will withstand as the duration of the stress is increased. Stress could be as high as $25 \%$ of the instantaneous breaking strength with reasonable chances of survival for 100 years. Thus, the maximum tensile stress in borosilicate waste glasses should be kept below $2300 \mathrm{lb} / \mathrm{in}^{2}$. A

* H. A. Elliott, Proc. Phys. Soc., vol. 59, p. 208, 1947.

** J. E. Stanworth, Physical Properties of Glass, Oxford University Press, London, 1950.

+ A. J. Holland and W.E.S. Turner, J. Soc. Glass Tech., Trans., vol. 20, p. 279, 1936. 
working stress* of about 30 to $50 \%$ of this value should probably be chosen to account for uncertainties in material variation, physical properties, and the very long-term stress behavior.

Internal Stress in Waste Glass

The internal stress within the solid due to internal gas buildup was calculated from the helium density distribution in the glass. The internal stress is equated to the internal gas pressure, which is obtained from the solubility of helium in the glass. The gas density within any voids in the solid is given by

$$
\rho(x, t)=\frac{C(x, t)}{S}
$$

where $\mathrm{C}$ is the helium density in the glass in atoms $/ \mathrm{cm}^{3}$ and $\mathrm{S}$ is the solubility expressed by the solid to gas helium density ratio at equilibrium. The internal gas pressure was then calculated using the ideal gas law. The solubility of helium in glass has been found to be independent of pressure;** however, the bulk strain of the glass due to internal stress could increase the internal gas volume by 10 to $15 \%$ for the range of allowable working stresses, and reduce the internal gas pressure proportionately. The maximum internal stress for typical waste glasses at $200^{\circ} \mathrm{C}$ occurs near the bottom of the can and for $\mathrm{LWR}_{\mathrm{UO}}$ fuel waste is about twice the allowable working stress. However, the glass containing $\mathrm{Pu}$ recycle fuel waste has an internal stress about 50 times higher than the allowable working stress, and surely will not survive without extensive cracking.

* C. O. Harris, Introduction to Stress Analysis, p. 61, The MacMillan Company, New York, 1959.

* S. P. Faile and D. M. Roy, "Gas Solubility in Relation to the Structures of Glasses and Liquids," J. Amer. Ceram. Soc., vol. 56, no. 1, pp. 12-16, 1973. 
One method of reducing the maximum internal stress in waste glass is to reduce the sample size so that the helium can diffuse toward a free surface. The results of a study of the geometry dependence of the maximum internal stress in a LWR $\mathrm{UO}_{2}$ fuel waste glass are shown in Figure 6 . The time at which the maximum internal stress occurs is increased, due to the helium diffusion phenomena, as the slab thickness or sphere radius is increased. The difference between the helium production rate and leakage rate (due to diffusion) is directly proportional to the rate of change in internal stress in the glass. These results indicate that slab thicknesses and sphere radii less than about 4 to $8 \mathrm{~cm}$ should be used to solidify LWR UO fuel $_{2}$ waste in glass if cracking is to be avoided.

\section{Conclusions}

The results of this study predict large structural stresses in waste glass canisters due to helium production from the actinide nuclides which decay naturally by alpha particle emission. The internal stress in the glass is mainly dependent on the solubility of helium, which is unknown for the complicated borosilicate formulations used as high-level waste fixation media. The mechanical properties of these waste glasses were assumed to be similar to other glasses but, in fact, are not well known. Reducing the size of individual waste glass specimens, using an array of close-packed spheres, would provide a means to take advantage of helium diffusion phenomena in reducing the internal stress in waste glasses. Experiments are planned which will verify the conditions which produce cracking in waste glass. 


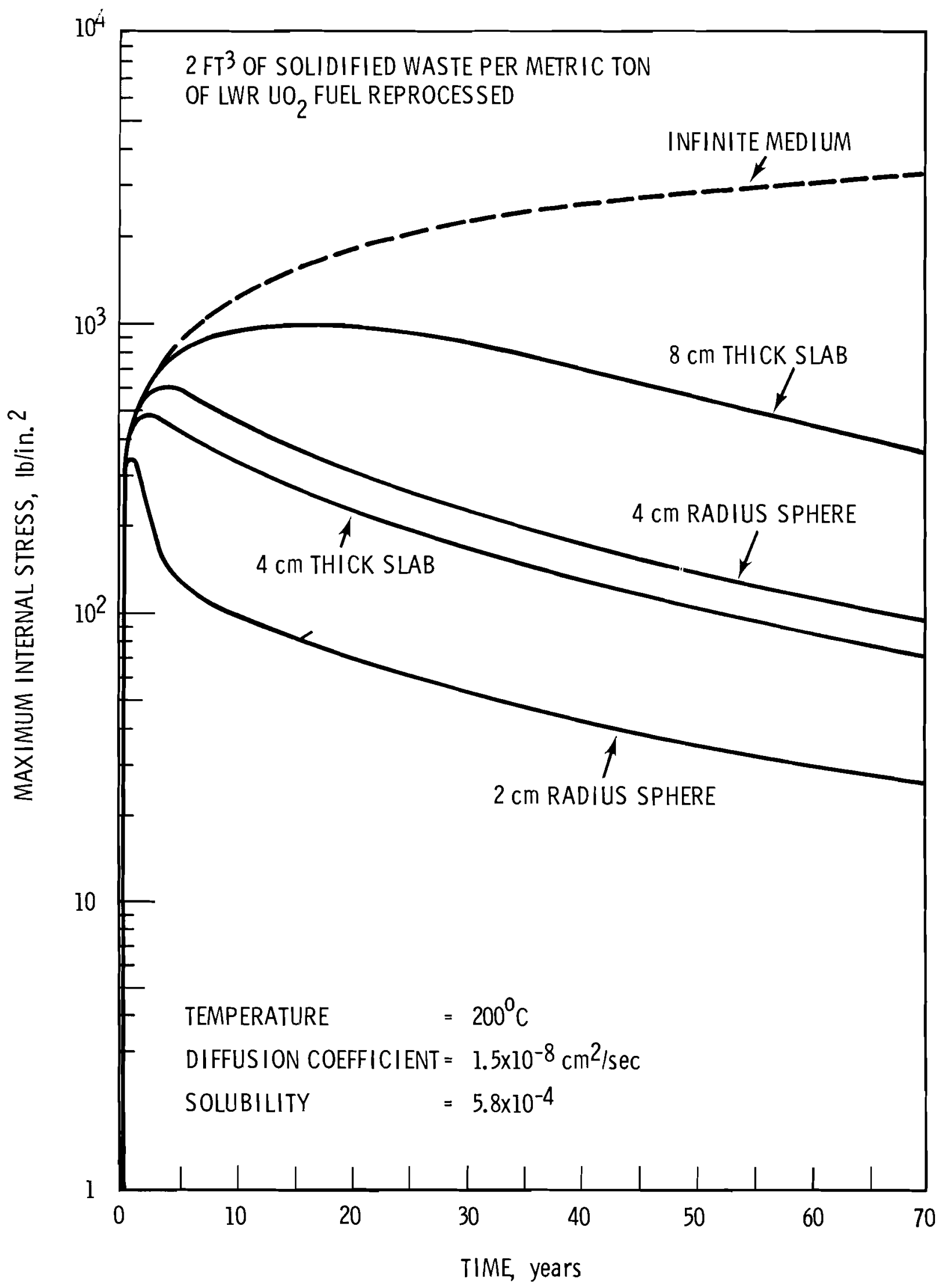

FIGURE 6. Time Dependent Maximum Internal Stress in Waste Glass for Different Sample Geometries 
No. of Copies

OFFSITE

UNITED STATES

$1 \quad$ AEC Chicago Patent Group

A. A. Churm

AEC Directorate of Licensing for Fuels and Materials 4915 St. Elmo Ave. Bethesda, MD 20014

Deputy Director for Fuels and Materials

S. H. Smiley

Chief, Technical Support Branch for Fuels and Materials

R. B. Chitwood

1 AEC Division of Biomedical and Environmental Research

W. G. Belter

2 AEC Division of Production and Materials Management

F. P. Baronowski

W. L. Lennemann

2 AEC Division of Reactor Research and Development

Assistant Director for Reacior Technology

E. E. Sinclair

Chief, Fuel Recycle Branch

W. H. McVey

$7 \quad$ AEC Division of Waste Management and Transportation

G. H. Daly

W. K. Eister

O. P. Gormley

A. F. Perge

F. K. Pittman

R. W. Ramsey

R. D. Walton

$1 \quad$ AEC Idaho Operations Office

K. K. Kennedy

$$
\text { Distr }-1
$$


No. of

Copies

1 AEC Oak Ridge Operations Office

E. H. Hardison

1 AEC Office of the Commissioners

W. H. Beach, Technical Assistant to Commissioner C. E. Larson

1 AEC Savannah River Operations Office

P. D. Fairchild

194 AEC Technical Information Center

4 Allied Chemical Corporation Idaho Falls, ID 83401

J. A. Buckham

B. R. Dickey

C. M. Slansky

B. R. Wheeler

3 Allied-Gulf Nuclear Services P. O. Box 847

Barnwell, SC 29812

B. M. Legler

G. R. Bray

A. Schneider

1 Argonne National Laboratory

R. C. Vogel

1 Bechtel Corporation

50 Beale Street

San Francisco, CA 94119

1 Burns and Roe, Inc.

700 Kinderamack Road

Oradell, NJ 07649

P. P. DeRienzo

2 Dow Chemical Company (AEC)

D. L. Ziegler

M. A. Thompson 
No. of

Copies

3

duPont Company, Aiken (AEC)

C. H. Ice

A. S. Jennings

L. H. Meyer

1 duPont Company, Wilmington (AEC)

A. A. Johnson

2 Environmental Protection Agency

Parklawn Building

5600 Fishers Lane

Rockville, MD 20852

C. G. Meyers

1 Environmental Protection Agency

P. O. BOX 15027

Las Vegas, NV 89114

B. Mann

1 Environmental Protection Agency

5555 Ridge Àvenue

Cincinnati, OH 45213

R. E. Landreth

1 General Electric Company

175 Curtner Avenue

(M/C 160)

San Jose, CA 95125

R. G. Barnes

1 General Electric Company

Midwest Fuel Recovery Plant Route 1, Box 219-B

Morris, IL 60450

R. Lambert

2 General Electric Company

Vallecitos Nuclear Center

Vallecitos Road

Pleasanton, CA 94566

W. H. Reas

Distr -3 
No. of

Copies

3

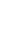

1

1

National Lead Company
Ill Broadway
New York, NY 10006

Stephen Brown

1 National Academy of Sciences

Committee of Radioactive Waste Management

National Research Council

2101 Constitution Avenue

Washington, DC 20418

D. Cyrus Klingsberg, Tech. Secretary

2 Nuclear Fuel Services, Inc.

P.O. Box 124

West Valley, NY 14171

J. P. Duckworth, Plant Manager

6000 Executive Blvd., Suite $60 \mathrm{C}$

Rockville, MD 20852

E. D. North, Director of Technical Administration

1 NYS Atomic and Space Development Authority

230 Park Ave., Rm. 2425

New York, NY 10017

J. G. Cline, General Manager

4 Oak Ridge National Laboratory (AEC)

Central Research Library,

Document Reference section

Central Research Library, ORNL

Laboratory Records Dept., ORNL

Laboratory Records Dept., ORNL-RC

3 Union Carbide Corporation (ORNL)

A. L. Boch

J. O. Blomeke

Ferruccio Gera

Distr -4 
No. of

Copies

2

Sandia Laboratories

Albuquerque, NM 87107

A. C. Zuppero

R. L. Hagengruber

FOREIGN

$1 \quad$ EURATOM

Health Physics Division

29, Rue Aldringer

Luxembourg, BELGIUM

Rene Amavis

1 Studiecentrum voor Kernenergie (Mol)

SCK, CEN

Boeretang, 200

2400 Mol. BELGIUM

P. Dejonghe

1 Atomic Energy Research Establishment

Harwell, Didcot, Berks, ENGLAND

K. D. B. Johnson

1 United Kingdom Atomic Energy Authority

Risley, ENGLAND

D. W. Clelland

2 Centre de Marcoule

B. P. 106

30 - Bagnols S/Ceze

FRANCE

R. Bonniaud

3 Centre d'Etudes Nucleaires de Fontenay-aux-Roses

Boite Postale 6

92 - Fontenay-aux-Roses

FRANCE

P. J. Regnaut

J. Sauteron

Y. J. Sousselier

1 Bundesministerium für Bildung und Wessenschaft

D53 Bonn 12

Postfach 120124

GERMANY

R. P. Randl 
No. of

Copies

1 Gesellschaft für Strahlen und Umwellforschung

Institut fur Tieflogerung

3392 Clausthal-zellerfeld

Bornhardstr. 22

GERMANY

K. Kühn

1 Hahn-Meitner-Institut

1 Berlin 39

Glienickerstr. 100

GERMANY

Hans W. Levi

2 Institut für Chemische Technologie

Kernforscinungsanloge Julich GmbH

D517 Julich

Postfach 365

GERMANY

E. R. Merz

K. H. Rattay

$1 \mathrm{MGH} / \mathrm{GWK} / \mathrm{Wiederacifurbeitung} \mathrm{-} \mathrm{Sanlage/WAK}$

Karlsruhe, GERMANY

W. A. Issel

2 Nuclear Research Center

Waste Management Dept.

D75 Karlsruhe

Weberstr. 5

GERMANY

H. Krause

2

CNEN

Directtore of Programma Eurex Del CNEN

Saluggia "Vercelli", ITALY

Giacomo Calleri

Laboratorio di Ingegneria Sanitaria

Via Anguillarese $\mathrm{km} 1+300$

Roma, ITALY

Willy Bocola 
No. of

Copies

1

Bhabha Atomic Research Centre

Organic Waste Laboratory

Plutonium Plant site

Trombay, Bombay,

INDIA

Keshava Chandra

2

Bhabha Atomic Research Centre

Waste Treatment Division

Trombay, Bombay,

INDIA

N. S. Sunder Rajan

K. T. Thomas

1 India Atomic Energy Establishment

Waste Treatment Plant \& Decontamination Center Bombay 85 , INDIA

Victor Amalraj, Plant Superintendent

2 International Atomic Energy Agency

Kartner Ring 11

P.O. Box 590

A-1011, Vienna, AUSTRIA

1 Dr. H. F. Ramdohr

c/o Friedrich Uhde $\mathrm{GmbH}$

46 Durtmund

Deggingstr. 10-12

GERMANY

\section{ONSITE}

1

AEC/RL Patent Attorney

R. W. Poteat

3 AEC Richland Operations office

Production and Waste Management Programs Division

O. J. Elgert

Research and Development Programs Division

B. J. Melton

1 AEC/RL Environmental, Safety and Technical Services Division

P. G. Holsted 
No. of

Copies

12

32

\section{Battelle-Northwest}
E. L. Alpen
R. J. Bashor
J. L. Bates
W. F. Bonner
N. E. Carter
T. D. Chikalla
D. L. Condotta
G. M. Dalen
R. D. Dierks
J. N. Hartley
G. Jansen
J. D. Kaser

J. L. MCElroy (5)

J. E. Mendel

D. F. Newman

A. M. Platt

A. K. Postma

J. Posakoni

K. J. Schneider

D. H. Siemens

W. H. Swift

W. K. Winegardner Technical Information Technical Publications

2

Exxon

Richland, WA 99352

S. J. Beard

L. T. Lakey

2 United Nuclear Industries, Inc.

2 Westinghouse Hanford Company

G. L. Richardson

C. R. Cooley 